\title{
Targeting Biofilms Therapy: Current Research Strategies and Development Hurdles
}

\author{
Yu Jiang, Mengxin Geng and Liping Bai * \\ NHC Key Laboratory of Biotechnology of Antibiotics, CAMS Key Laboratory of Synthetic Biology for \\ Drug Innovation, Institute of Medicinal Biotechnology, Chinese Academy of Medical Sciences \& Peking Union \\ Medical College, Beijing 100050, China; JiangYu_WJ@163.com (Y.J.); gengmengxin@126.com (M.G.) \\ * Correspondence: lipingbai1973@163.com; Tel.: +86-10-63013336
}

Received: 7 July 2020; Accepted: 7 August 2020; Published: 11 August 2020

\begin{abstract}
Biofilms are aggregate of microorganisms in which cells are frequently embedded within a self-produced matrix of extracellular polymeric substance (EPS) and adhere to each other and/or to a surface. The development of biofilm affords pathogens significantly increased tolerances to antibiotics and antimicrobials. Up to $80 \%$ of human bacterial infections are biofilm-associated. Dispersal of biofilms can turn microbial cells into their more vulnerable planktonic phenotype and improve the therapeutic effect of antimicrobials. In this review, we focus on multiple therapeutic strategies that are currently being developed to target important structural and functional characteristics and drug resistance mechanisms of biofilms. We thoroughly discuss the current biofilm targeting strategies from four major aspects-targeting EPS, dispersal molecules, targeting quorum sensing, and targeting dormant cells. We explain each aspect with examples and discuss the main hurdles in the development of biofilm dispersal agents in order to provide a rationale for multi-targeted therapy strategies that target the complicated biofilms. Biofilm dispersal is a promising research direction to treat biofilm-associated infections in the future, and more in vivo experiments should be performed to ensure the efficacy of these therapeutic agents before being used in clinic.
\end{abstract}

Keywords: microbial resistance; biofilm; EPS; enzyme; antibodies; quorum sensing; metabolic; AMP

\section{Introduction}

Previous work has revealed that the nature and structure of biofilms is one of the reasons behind drug resistance, which also includes nutrient and oxygen availability to the bacterial cells and intrinsic and acquired bacterial resistance [1]. Approximately $80 \%$ of chronic and recurrent microbial infections in humans are caused by bacterial biofilms [2]. Being in a biofilm provides microbes plenty of survival advantages, including, but not limited to, the protection of microbes from the host immune system and antimicrobials/antibiotics, water retention, tolerance to desiccation, sorption and storage nutrient, high extracellular enzymatic activity, adhesion to the infection site, and cell aggregation inducing coordination of virulence factor expression via quorum sensing (QS) [3-5]. Traditional treatment of microbial infections is by directly targeting the causative pathogens. However, the presence of biofilms elevated the effective concentrations of antibiotics to a much higher level, and microorganisms in biofilms may develop tolerance to antimicrobial agents through metabolic dormancy or molecular persistence programs that cause the recurrence of biofilm infections after a long period of clinical quiescence.

Biofilm recalcitrance is a result of complex physical and biological characteristics with multiple microbial genetic and molecular factors. It often involves multi-species interactions, so the efficacy of treating biofilm infections with antibiotic alone is poor. Recently, many researchers have switched their focus to anti-biofilm agents, expecting to enhance the efficacy of traditional antibiotic therapies through 
inhibition of biofilms formation and dispersal of bacteria within mature biofilms that releases the biofilm-associated microbes into their more vulnerable, planktonic state. Dispersion of mature biofilm can be divided into two approaches - active dispersal and passive dispersal—both of which can release planktonic bacteria into the environment. Passive dispersal refers to physical dispersion caused by mechanical intervention or external forces, such as toothbrushing or torn down from the main mass by the flow of interstitial fluid. Active dispersal refers to spontaneous dispersal event of biofilm-associated microbes themselves in response to environmental changes such as nutrient starvation, toxic byproducts, bacteriophages, phagocyte challenge, antimicrobial stress, and unfavorable oxygen levels [6]. Active dispersal is a crucial stage within the lifecycle of a biofilm and is conducive to bacterial survival and disease progression. Therefore, in this review, we focus on four main ways to disperse bacterial biofilm, including targeting the extracellular polymeric substance (EPS) matrix, dispersal molecules, targeting QS, and targeting dormant cells, expecting to induce active dispersal event via external interference. Various mechanical dispersion methods that are being developed, such as improving debridement techniques and surface modification technologies, are only briefly mentioned in conventional treatment methods, without in-depth discussion.

\section{Conventional Treatment Methods}

Other than piled-up assemblages of clonal cells, microbial biofilms represent a dynamic self-constructed ecosystem with a high degree of heterogeneous and compartmentalized milieu [7]. Since the complicated microenvironment inside the biofilm shares similar characteristics with cancer, many biofilm management strategies being devised in clinic are largely based on approach from cancer treatment-early and aggressive irrigation and debridement for physically removal and local delivery of high and sustained antimicrobial chemotherapy [8]. Current biofilm targeting technologies can be divided into the following two groups: (1) physical-mechanical approaches such as high velocity spray and jet irrigators and (2) surface-coating and eluting substrates. Mechanical removal approaches, including debridement of surgical site infections to remove necrotic tissue, exudates, or dental biofilms, has been applied to remove clinical pathogenic biofilms [7]. Surface-coating and eluting substrates can be impregnated with antimicrobials to prevent biofilm formation, and several antimicrobial metal or inorganic coatings have also been applied in clinic to prevent biofilm formation [9]. However, for treating pre-existing biofilms, laboratory studies show that statistically significant reductions of biofilm may require extended incubation periods with high antibiotic concentrations. In situ releasing is an important approach to solve this problem, since higher localized antibiotic concentrations can be sustained for a longer period of time compared with systemic administration [10,11].

Furthermore, high-speed imaging has provided important information on fluid-biofilm-surface interactions, demonstrating that although a statistically significant amount of biofilm is removed from the area, the biofilm gets fluidized and spreads across the surface [12]. The low success rate of irrigation and debridement treatment in periprosthetic infections can be attributed to the ability to the fluidization of biofilms [7]. Nonetheless, antimicrobial agents can be conveniently supplied when using water-based jets-the fluid doubles can create mechanical forces to act on the biofilms while drugs being delivered to act on pathogens at the same time. Despite clinical therapies discussed above having made some progress, mechanical removal methods still have many limitations, and the long-term existence of biofilms may also induce antibiotic resistance. All these problems indicate the urgent need for scientific researchers to seek other strategies for biofilms dispersal.

\section{EPS-Targeting Strategies}

The development of biofilm includes the following four stages: initial adhesion, early biofilm formation, biofilm maturation, and finally dispersal. Biofilms can be treated at each of the above-mentioned stages (see Figure 1). The EPS matrix is an essential component within these phases, which can promote adhesion to surface, cell-cell adhesion and aggregation [3], and also functions as a 3D scaffold that provides cohesiveness, mechanical stability and protection against 
host effectors and antimicrobial therapies [7]. In addition, the EPS matrix can dynamically modulate chemical and nutrient gradients, creating pathogenic environments (such as acidic $\mathrm{pH}$ and hypoxia) that conduct to the development of key virulence attributes, including recalcitrance [13,14]. Thus, targeting the EPS matrix may be an effective way to remove biofilm, disaggregate bacteria, and disrupt the pathogenic environment [15]. Targeting the EPS matrix can be achieved through the following ways: inhibit the EPS production, block the adhesion through binding to adhesins on the microbial surfaces, and degrade the EPS matrix in mature biofilms.

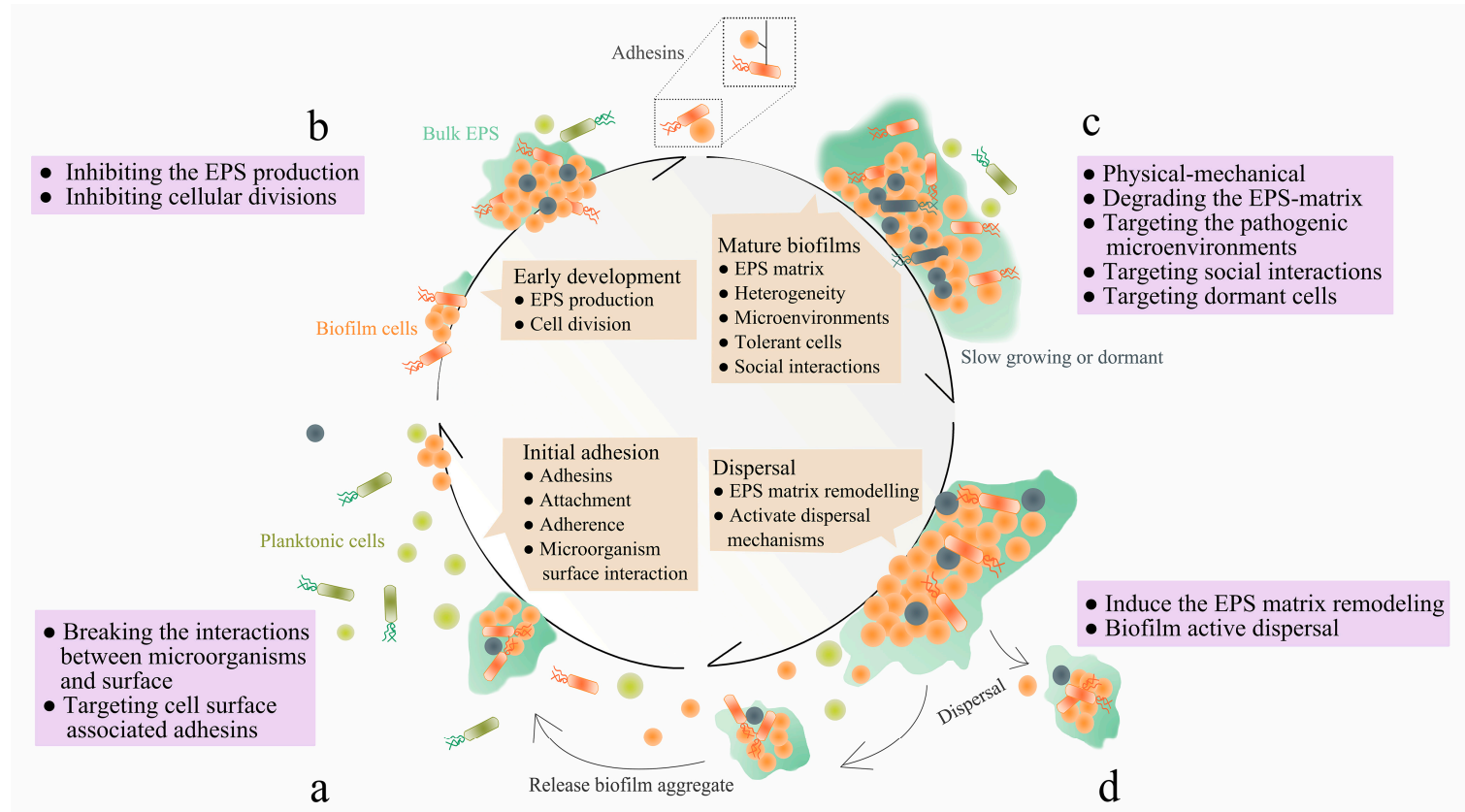

Figure 1. Four stages of biofilm formation: (a). "initial adhesion"-microorganisms bind to host or medical device surfaces through cell surface associated adhesins; (b). "early biofilm formation"-cells begin to divide and produce extracellular polymeric substance (EPS) to enhance adhesion, while form matrix that embeds the cells; (c). "biofilm maturation"-EPS matrix develops 3-D structures which is multi-functional and protective, allowing heterogeneous chemical and physical microenvironments to be formed where microorganisms co-exist within polymicrobial and social interactions; (d). "dispersal" — cells leave the biofilm, returning to the planktonic phase. Therapeutic interventions at each stage of the biofilm development. Supplemented and modified based on Figure 1 provided in [7]. Biofilms can be targeted at each stage. (a). For example, the initial phase of biofilm formation can be disrupted by breaking the interactions between microorganisms and surface, through targeting cell surface associated adhesins. (b). The early stages of biofilm development can be disrupted by inhibiting the EPS production and cellular divisions. (c). Mature biofilms can be removed by physical-mechanical approaches, degrading the EPS-matrix, targeting the pathogenic microenvironments and social interactions within polymicrobial biofilms, as well as eliminating dormant cells. (d). Induce the EPS matrix remodeling or biofilm active dispersal events.

\subsection{Targeting EPS Synthesis, Secretion and Adhesins}

The synthesis and secretion of EPS is a complicated process with the participation of both signaling networks and non-signaling mechanisms. In general, cyclic-di-GMP and cyclic-di-AMP [16] regulate various EPS-producing exo-enzymes, polysaccharides and adhesins, which are potential candidates to be targeted to inhibit or disrupt EPS [17,18]. For example, glucosyltransferase (GTFs) that controls glucan production in the Gram-positive bacterium Streptococcus mutans are regulated by these nucleotide-signaling molecules. Signaling molecule inhibitors which can inhibit the synthesis of Glucan will cause the reduction of pathogenic biofilms accumulation. Using these small molecule inhibitors alone is not superior to the chemicals that are currently in use for biofilms control, 
like chlorhexidine, but when used in combination, these inhibitors can greatly enhance the therapeutic effects of chemicals $[19,20]$. Some researchers have also identified several potential small molecule inhibitors of di-guanylate or di-adenylyl cyclase through library screening, or in silico drug discovery combined with bioactivity assessment using in vitro biofilm models [21,22], and has been proved to have potential application value.

Furthermore, inhibitors that target the production of adhesin, and adhesin-binding antibodies or peptides can also break the interactions between microorganisms and host surface. For example, mannosides that target the bacterial type 1 fimbrial adhesin FimH have been demonstrated to prevent catheter-associated urinary tract infections (UTI) in mice by reducing Escherichia coli UTI89 colonization and treat chronic cystitis by reducing the E. coli EC958 population [23-25]. However, the metabolic instability of O-glycoside linkage may result in the low half-life and bioavailability of mannosides, and this can be addressed through replacing O-mannosides with C-mannosides. Experimental results showed that prophylactic treatment with $\mathrm{C}$-mannosides reduced the $E$. coli burden for 2-log's and treatment of chronic infection resulted in a 4-log reduction in an UTI mouse model [26]. Alkyl-substituted mannose residues can access 100-folds higher affinities to E. coli adhesin FimH than mannose [27], and arylmannoside also displays low nanomolar binding affinity to FimH, which is likely due to the hydrophobic interactions with the isoleucine and two tyrosines residues within the binding pocket [28]. These optimizations have improved their affinities significantly, increasing the practicability of potential carbohydrate-based drugs. Similarly, ring-fused 2-pyridones, which can inhibit the biogenesis of curli and type- 1 pili, has been shown to reduce the uropathogenic E. coli bladder colonization for more than 10-fold in an in vivo mouse UTI model [29]. Other biomolecules that bind to EPS adhesins have been extensively discussed previously [30]. Table 1 summarizes some of the biomolecules as examples.

Table 1. Biomolecules that target EPS synthesis, secretion, and adhesins.

\begin{tabular}{|c|c|c|}
\hline \multicolumn{3}{|c|}{ Biomolecules That Target EPS Synthesis and Secretion } \\
\hline Name & Summary & References \\
\hline $\begin{array}{c}\text { 2-(4-methoxyphenyl)-N- } \\
\text { (3-\{[2-(4-methoxyphenyl)ethyl]imino\}- } \\
\text { 1,4-dihydro-2- } \\
\text { quinoxalinylidene)ethanamine }\end{array}$ & $\begin{array}{l}\text { A kind of quinoxaline derivative which inhibits } \\
\text { extracellular polymeric substance (EPS) synthesis } \\
\text { and biofilm formation in Streptococcus mutans by } \\
\text { selectively antagonizing Gtfs instead of killing } \\
\text { the bacteria directly. }\end{array}$ & {$[19]$} \\
\hline tt-farnesol & $\begin{array}{l}\text { Targets the expression of key genes during } \\
\text { biofilm formation. Those key genes are } \\
\text { associated with exopolysaccharide matrix } \\
\text { synthesis }(g t f B) \text { and exogenous stress modulation } \\
\text { (e.g., slo } A \text { ) that are essential for cariogenic biofilm } \\
\text { assembly. It has been proved to be effective } \\
\text { against } S . \text { mutans in vitro and in vivo. }\end{array}$ & {$[20]$} \\
\hline myricetin & $\begin{array}{l}\text { Targeting the expression of key genes during } \\
\text { biofilm formation in vitro and in vivo. Key genes } \\
\text { are associated with exopolysaccharide matrix } \\
\text { synthesis }(g t f B) \text { and exogenous stress modulation } \\
\text { (e.g., sloA) that are essential for cariogenic biofilm } \\
\text { assembly. It has been proved to be effective } \\
\text { against } S . \text { mutans and Escherichia coli. }\end{array}$ & {$[20,31]$} \\
\hline Ring-fused 2-pyridones & $\begin{array}{l}\text { A member of curlicides, such as FN075 and } \\
\text { BibC6, sharing a common chemical lineage with } \\
\text { other ring-fused 2-pyridones termed pilicides. } \\
\text { Retain pilicide activities and inhibit both } \\
\text { curli-dependent and type 1-dependent biofilms. }\end{array}$ & [29] \\
\hline Temporin-GHc, Temporin-GHd & $\begin{array}{l}\text { Impede the initial adhesion of biofilm and } \\
\text { downregulate the expression of } \\
\text { glucosyltransferases biosynthesis genes, having } \\
\text { been proved to be effective against } S \text {. mutans. }\end{array}$ & {$[32]$} \\
\hline
\end{tabular}


Table 1. Cont.

\begin{tabular}{|c|c|c|}
\hline \multicolumn{3}{|c|}{ Biomolecules That Target EPS Synthesis and Secretion } \\
\hline Name & Summary & References \\
\hline \multicolumn{3}{|c|}{ Biomolecules that Target Adhesins } \\
\hline Mannosides & $\begin{array}{l}\text { A small molecule inhibitor of type } 1 \text { fimbriae } \\
\text { adhesin FimH that effectively inhibit the invasion } \\
\text { of E. coli. }\end{array}$ & {$[23,25]$} \\
\hline ZFH-04269 & $\begin{array}{l}4^{\prime}-\left[\alpha \text {-d-Mannopyranosyloxy]-N, } 3^{\prime}-\right. \\
\text { dimethylbiphenyl-3-carboxamide, a small } \\
\text { molecular weight compound which inhibits the } \\
\text { type } 1 \text { fimbriae adhesin FimH and significantly } \\
\text { reduces E. coli colonization. }\end{array}$ & {$[24]$} \\
\hline C-mannosides & $\begin{array}{l}\text { Replacing O-mannosides with C-mannosides to } \\
\text { improve the half-life and bioavailability of } \\
\text { mannosides, which was due to the metabolic } \\
\text { instability of O-glycoside linkage. C-mannosides } \\
\text { have been proved to effectively reduce the E. coli } \\
\text { burden. Alkyl-substituted mannose residues also } \\
\text { have } 100 \text {-fold higher affinities to the E. coli } \\
\text { adhesin FimH than mannose. }\end{array}$ & {$[26,27]$} \\
\hline Arylmannoside & $\begin{array}{l}\text { Arylmannoside displays low nanomolar binding } \\
\text { affinity to FimH, which is likely due to its } \\
\text { hydrophobic interactions with the isoleucine and } \\
\text { two tyrosine resodies within the binding pocket. }\end{array}$ & {$[28]$} \\
\hline FUD & $\begin{array}{l}\text { An inhibitory protein that targets } \\
\text { Candida-fibronectin interactions by blocking the } \\
\text { surface adhesion of Candida to halt biofilm } \\
\text { formation. }\end{array}$ & [33] \\
\hline NDV-3A & $\begin{array}{l}\text { A vaccine based on the } \mathrm{N} \text {-terminus of Als } 3 \\
\text { protein formulated with alum and has been } \\
\text { proved to be effective against biofilm formed by } \\
\text { Candida auris. }\end{array}$ & {$[34]$} \\
\hline
\end{tabular}

\subsection{Targeting EPS Chemical Composition}

Biofilms are formed when microbes irreversibly attach to a surface, begin to divide, and provide more diverse adhesion sites to recruit other microorganisms to the substrate [35]. Biofilms are a self-synthesized layer that microorganisms used to protect their microbial communities, consisting of complex polysaccharides, proteins, lipids, and extracellular DNA (eDNA), collectively called extracellular polymeric substance (EPS) [3]. The composition of the EPS matrix is variable both temporally and structurally, depending on the type of microorganisms, local mechanical shear forces, substrate availability, and the host environment [7].

One of the main approaches that bacteria use to achieve active dispersal is to produce extracellular enzymes that act on various structural components of EPS, such as proteins, eDNA, and exopolysaccharides, to promote biofilm dispersion and turn bacteria back to the more vulnerable, planktonic state. Targeting EPS can also destroy the viscoelasticity properties to further weaken the cohesiveness of biofilm and enhance antimicrobial efficacy. Theoretically, clinicians can isolate and purify these enzymes and exogenously apply them to pre-formed biofilms at high concentrations in order to achieve active dispersal. Here, three classes of enzymes that have been studied for biofilms dispersal is reviewed: proteases, deoxyribonucleases, and glycoside hydrolases.

\subsubsection{Proteases}

Extracellular proteins are major components of EPS that represent a large portion of biofilm's dry mass [36-39] and are crucial for microbes to maintain and modify the EPS [40,41]. Certain proteins, such as DNA-binding proteins (DNABPs), functional amyloids/amyloid-like proteins (FA/ALPs), and other biofilm-associated proteins (Baps), are vital contributors to the adhesion property and 
physical stability of biofilm matrices [6]. Thus, proteases that can degrade EPS extracellular proteins have the potential to disperse a massive biofilm.

A plethora of proteases that are conducive to biofilm dispersal have been identified, such as serine protease Esp secreted by a subset of Staphylococcus epidermidis. Purified Esp inhibits biofilm formation and destroys pre-existing Staphylococcus aureus biofilms, enhances the susceptibility of S. aureus that are embedded in biofilms to an antimicrobial peptide component of the human innate immune system-human beta-defensin 2 (hBD2) [42]. In addition, $2 \mu \mathrm{g} / \mathrm{mL}$ proteinase $\mathrm{K}$ can also effectively inhibit biofilm development in bap-positive S. aureus V329, as well as other S. aureus isolates (SA7, SA10, SA33, SA352), and significantly enhance the efficacy of gentamicin against all S. aureus biofilms tested [43]. According to the latest report, cysteine proteases that are secreted by equine mesenchymal stromal cells (MSCs) can destabilize methicillin-resistant Staphylococcus aureus (MRSA) biofilms, increasing the efficacy of antibiotics that were previously tolerated by biofilms [44]. Table 2 summarizes some of the proteases that have shown anti-biofilm activities.

Table 2. Proteases that target extracellular proteins. Supplemented and modified based on information provided in [6].

\begin{tabular}{|c|c|c|}
\hline Name & Summary & References \\
\hline Esp & $\begin{array}{l}\text { A kind of serine protease secreted by a subset of } \\
\text { Staphylococcus epidermidis. Purified S. epidermidis serine } \\
\text { protease (Esp) can inhibit biofilm formation and destroy } \\
\text { pre-existing Staphylococcus aureus biofilms. }\end{array}$ & [42] \\
\hline Cysteine Proteases & $\begin{array}{l}\text { Cysteine proteases secreted by equine mesenchymal } \\
\text { stromal cells (MSCs) has been shown to destabilize } \\
\text { methicillin-resistant Staphylococcus aureus (MRSA) } \\
\text { biofilms, thereby increasing the efficacy of antibiotics } \\
\text { that were previously tolerated by the biofilms } \\
\text { (penicillin/streptomycin), and the equine MSCs } \\
\text { secretome can inhibits biofilm formation of various } \\
\text { bacteria, such as Pseudomonas aeruginosa, S. aureus, } \\
\text { and S. epidermidis. }\end{array}$ & {$[44]$} \\
\hline Aureolysin (Aur) & $\begin{array}{l}\text { A staphylococcal metalloprotease that has been shown to } \\
\text { disrupt } S \text {. aureus biofilms by degrading Bap and } \\
\text { clumping factor b. }\end{array}$ & {$[45,46]$} \\
\hline LapG & $\begin{array}{l}\text { A protease produced by Pseudomonas putida and has been } \\
\text { shown to trigger biofilm dispersal event through } \\
\text { modification of the outer membrane-associated and } \\
\text { exopolysaccharide-binding protein LapA. }\end{array}$ & [47] \\
\hline Proteinase K & $\begin{array}{l}\text { A highly reactive and stable serine protease with a broad } \\
\text { range of cleavage activity that targets peptide bonds } \\
\text { which are adjacent to the carboxylic group of aliphatic } \\
\text { and aromatic amino acids. It is active against the } \\
\text { biofilms produced by a wide range of bacteria strains, } \\
\text { including S. aureus, Listeria monocytogenes, Staphylococcus } \\
\text { lugdunensis, Staphylococcus heamolyticus, Gardnerella } \\
\text { vaginalis, and E. coli, Heamophilus influenza, } \\
\text { and Bdellovibrio bacteriovorus. }\end{array}$ & [48-55] \\
\hline Spl & $\begin{array}{l}\text { A group of six Staphylococcal serine proteases that are } \\
\text { involved in S. aureus biofilm dispersal, possibly through } \\
\text { the cleavage of a cell wall-associated protein EbpS. }\end{array}$ & {$[56,57]$} \\
\hline
\end{tabular}


Table 2. Cont.

\begin{tabular}{clc}
\hline Name & \multicolumn{1}{c}{ Summary } & References \\
\hline ScpA, SspB & $\begin{array}{l}\text { Belongs to Staphylococcal cysteine proteases and have } \\
\text { been shown to disperse S. aureus biofilms through } \\
\text { degrading unknown target(s). }\end{array}$ & {$[45,58]$} \\
& $\begin{array}{l}\text { A Streptococcus pyogenes cysteine protease which has } \\
\text { recently been shown to be involved in in vivo dispersal } \\
\text { of S. pyogenes biofilms through the hydrolysis of surface } \\
\text { proteins M and F1, which are hypothesized to be } \\
\text { involved in microcolony formation. }\end{array}$ & [59-61] \\
\hline SpeB & $\begin{array}{l}\text { An endogenous Streptococcal protease which results in S. } \\
\text { mutans monolayer biofilm detachment from colonized } \\
\text { surface through releasing the surface protein antigen P1. }\end{array}$ & [62] \\
\hline Trypsin & $\begin{array}{l}\text { A member of pancreatic serine protease that cleaves } \\
\text { peptides at the carboxyl side of lysine or arginine, and } \\
\text { actives against biofilms produced by multiple bacterial } \\
\text { species, including P. aeruginosa, Streptococcus mitis, } \\
\text { Actinomyces radicidentis, S. epidermidis, and G. vaginalis. }\end{array}$ & {$[48,55,63,64]$} \\
\hline SspA & $\begin{array}{l}\text { A staphylococcal serine protease that degrades fibronectin } \\
\text { binding proteins and Bap in S. aureus biofilms. }\end{array}$ & {$[46,65]$} \\
\hline
\end{tabular}

\subsubsection{Deoxyribonuclease (DNase)}

Extracellular DNA (eDNA) functions as a structural scaffold within the EPS in many biofilms, facilitating the bacterial adhesion, aggregation, and horizontal gene transfers [66-70]. Initially, DNA found within biofilms was considered to be leftovers of lysed cells, until eDNA was shown to be a vital contributing component of bacterial biofilms by Whitchurch et al. in 2002 [66], and this finding has also triggered a wave of research trying to destroy biofilms by targeting eDNA with DNases. But in reality, deoxyribonuclease (DNase) has been used to decrease sputum viscosity in cystic fibrosis patients even before the function of eDNA in biofilms was discovered [71]. Current antibiotic treatment of biofilms in the lungs of cystic fibrosis patients is complemented with recombinant human DNase I (rhDNase I) [72]. Mammalian DNase I needs to be glycosylated after translation [73], which precludes the use of cheaper prokaryotic expression systems. rhDNase I used in treatment of cystic fibrosis is produced in mammalian cells, whereas the bovine DNase I commonly used in vitro is purified from bovine pancreas [74]. An active but non-glycosylated version of bovine pancreatic DNase I can be expressed in E. coli [75], but glycosylation is required for its full activity and thermal stability [73]. Thus, the scope for using DNase in large-scale biotechnological applications is currently limited by its high cost [76]. DNase I overexpression has been developed in Pichia pastoris [77], which may reduce the production cost. It has been shown that bovine DNase I can statistically significantly decrease Gardnerella vaginalis colonization on vaginal mucosal epithelial cells in a murine model [78].

Exogenous DNase I is effective against the biofilms of many Gram-negative and Gram-positive bacteria, but its effect is dependent on the age of biofilms [74]. Young biofilms are easily removed, but DNase treatment will no longer be effective once the biofilm ages pass a certain point [74] — for example, $12 \mathrm{~h}$ for S. epidermidis [79], $80 \mathrm{~h}$ for Pseudomonas aeruginosa [66], and $72 \mathrm{~h}$ for Vibrio cholerae [80]. The reason that biofilms get resistance to DNases remains unknown, suggesting that destabilizing biofilms by enzymatic degradation of the extracellular matrix should be combined with enzymes that not only target eDNA, but also polysaccharides and proteins [74]. Table 3 lists some of the DNases that have been demonstrated to have anti-biofilm activity. 
Table 3. DNases that targets extracellular proteins. Supplemented and modified based on information provided in [6].

\begin{tabular}{|c|c|c|}
\hline Name & Summary & References \\
\hline DNase I & $\begin{array}{l}\text { It has been demonstrated that pancreatic deoxyribonuclease } \\
\text { (DNase) can deconstruct the established biofilms of a wide range of } \\
\text { microbes, including P. aeruginosa, Vibrio cholerae, E. coli, S. pyogenes, } \\
\text { Klebsiella pneumoniae, Acinetobacter baumannii, Aggregatibacter } \\
\text { actinomycetemcomitans, Shewanella oneidensis, S. heamolyticus, } \\
\text { Bordetella pertussis, Bordetella bronchiseptica, Campylobacter jejuni, } \\
\text { H. influenza, B. bacteriovorus, S. aureus, Enterococcus faecalis, } \\
\text { L. monocytogenes, Candida albicans, and Aspergillus }\end{array}$ & [74] \\
\hline$\lambda$ Exonuclease & $\begin{array}{l}\text { A kind of viral DNase that can disrupt established } \\
\text { V. cholerae biofilms. }\end{array}$ & [80] \\
\hline DNase1L2 & $\begin{array}{l}\text { A human DNase found in keratinocytes that has been } \\
\text { demonstrated to degrade the established biofilms of } P \text {. aeruginosa } \\
\text { and S. aureus. }\end{array}$ & [81] \\
\hline Dornase alpha & $\begin{array}{l}\text { A highly purified form of recombinant human DNase I (rhDNase I), } \\
\text { which has been demonstrated to be effective against the established } \\
\text { biofilms of S. aureus, G. vaginalis and Streptococcus pneumoniae. }\end{array}$ & {$[72,78,82,83]$} \\
\hline NucB & $\begin{array}{l}\text { A bacterial DNase produced by the marine bacterium, } \\
\text { Bacillus licheniformis, which has been shown to be able to degrade } \\
\text { the established biofilms of multiple bacterial species, including } \\
\text { B. licheniformis, S. aureus, S. epidermidis, Staphylococcus salivarius, } \\
\text { Staphylococcus constellatus, S. Staphylococcus lugdunesis, } \\
\text { Staphylococcus anginosus, E. coli, Streptococcus intermedius, } \\
\text { Micrococcus luteus, and Bacillus subtilis. }\end{array}$ & [84-86] \\
\hline Streptodornase & $\begin{array}{l}\text { A streptococcal DNase that can disrupt the established biofilms of } \\
\text { P. aeruginosa. }\end{array}$ & [87] \\
\hline
\end{tabular}

\subsubsection{Glycoside Hydrolases}

Most biofilms are highly dependent on the presence of secreted exopolysaccharides as major EPS constituents $[3,88,89]$. Exopolysaccharides provide many important functions for the establishment and persistence of biofilms, including, but not limited to, structural stability, physical and chemical defense against antimicrobials and the host immune system, adhesion and aggregation of microbial cells, desiccation tolerance, sorption of organic and inorganic compounds, and providing a carbon source in times of nutrient starvation $[3,90,91]$. Considering the important role of exopolysaccharides in the establishment and maintenance of biofilm architecture, glycoside hydrolases that targeting exopolysaccharides in biofilms has become a research hotspot.

For instance, the glycoside hydrolases $\mathrm{PelA}_{h}$ and $\mathrm{PslG}_{\mathrm{h}}$ have been demonstrated to be able to disrupt biofilm integrity through degrading the key exopolysaccharides Pel and Psl within biofilm matrix in vitro, respectively. Besides, when treating P. aeruginosa-infected wounds, the combination of $P_{s l G}$ with tobramycin will trigger greater bacterial clearance than using tobramycin or $P_{s l G}$ alone. The combination can also improve the innate immune activity, resulting in greater complement deposition, neutrophil phagocytosis, and neutrophil reactive oxygen species production [92]. Although enzyme has the limitations of poor retention and enzymatic stability, which may compromise its efficacy in vivo [93], it has also been reported that the glycoside hydrolase can be used to degrade a mixed-species S. aureus and P. aeruginosa biofilm grown in a murine model of chronic wounds [93-95].

In addition, endolysins, a member of bacteriophage-encoded peptidoglycan hydrolases that can degrade the peptidoglycan layer of bacterial cell wall, has also attracted attention [96]. Engineered peptidoglycan hydrolase constructs with distinct antimicrobial activities have been proved to degrade multiple unique bonds in the $S$. aureus-specific peptidoglycan structure [97] and to increase bactericidal and biofilm removal in animal models. Fusion proteins, which are encoded by multiple bacteriophages 
and derived from endolysins with unique actions, may reduce the risk of resistance development and show sufficient specificity to avoid targeting commensal strains when supplied simultaneously [7]. Table 4 summarizes some of the glycoside hydrolases with biofilm-disrupting ability.

Table 4. Glycoside hydrolases that target extracellular proteins. Supplemented and modified based on information provided in [6].

\begin{tabular}{|c|c|c|}
\hline Name & Summary & References \\
\hline Cellulase & $\begin{array}{l}\text { A glycoside hydrolase produced by multiple microbes that } \\
\text { hydrolyzes the } \beta(1,4) \text { glycosidic linkage, and has been } \\
\text { demonstrated to induce the dispersal of biofilms formed by } \\
\text { S. aureus and P. aeruginosa. }\end{array}$ & [94] \\
\hline$\alpha$-mannosidase & $\begin{array}{l}\text { An acid hydrolase that is thought to be involved in the turnover of } \\
\text { N-linked glycoproteins and has been demonstrated to disrupt } \\
\text { P. aeruginosa biofilms. However, it has cytotoxic effect on A-431 } \\
\text { human epidermoid carcinoma cell lines. }\end{array}$ & {$[63,98]$} \\
\hline$\beta$ - mannosidase & $\begin{array}{l}\text { Hydrolyzes the terminal mannose residues, which are } \beta(1,4) \text { linked } \\
\text { to oligosaccharides or glycopeptides, can disrupt P. aeruginosa } \\
\text { biofilms. However, it has cytotoxic effect on A- } 431 \text { human } \\
\text { epidermoid carcinoma cell lines. }\end{array}$ & {$[63,99]$} \\
\hline Alginate lyase & $\begin{array}{l}\text { A glycoside hydrolase that degrades the exopolysaccharide alginate, } \\
\text { which is common in mucoid P. aeruginosa biofilms, causing bacterial } \\
\text { cell dispersal and increasing antibiotics' efficacy and phagocytosis. }\end{array}$ & [100-103] \\
\hline$\alpha$-amylase & $\begin{array}{l}\text { A glycoside hydrolase derived from multiple sources that } \\
\text { hydrolyzes } \alpha(1,4) \text { glycosidic linkages, mediating the dispersal of } \\
\text { mature biofilms of multiple bacterial strains, including } V \text {. cholerae, } \\
\text { S. aureus and P. aeruginosa. }\end{array}$ & {$[94,104-106]$} \\
\hline Dispersin B & $\begin{array}{l}\text { A glycoside hydrolase produced by A. actinomycetemcomitans, and } \\
\text { has been shown to degrade the polysaccharide } \\
\text { poly }(1,6)-N \text {-acetyl-d-glucosamine (PNAG) through hydrolyzing } \\
\beta(1,6) \text { glycosidic linkages. This enzyme can effectively act against } \\
\text { the biofilms formed by multiple bacteria, including S. aureus, } \\
\text { A. actinomycetemcomitans, S. epidermidis, A. baumannii, K. pneumoniae, } \\
\text { E. coli, Burkholderia spp., Actinobacillus Pleuropeumoniae, Yersinia } \\
\text { pestis and Pseudomonas fluorescens. }\end{array}$ & [107-114] \\
\hline Hyaluronidase & $\begin{array}{l}\text { An enzyme that cleaves hyaluronic acid (HA), a component which } \\
\text { has been found to be incorporated into the biofilms formed by } \\
\text { multiple pathogens, including S. aureus, and S. intermedius. } \\
\text { When utilized against HA-containing biofilms, biofilms dispersal } \\
\text { has been observed. }\end{array}$ & {$[115,116]$} \\
\hline $\mathrm{PelA}_{h}, \mathrm{PslG}_{\mathrm{h}}$ & $\begin{array}{l}\text { Glycoside hydrolases that can disperse mature biofilms formed by } \\
\text { P. aeruginosa through hydrolyzing the Pel or Psl polysaccharide, } \\
\text { respectively. }\end{array}$ & [117] \\
\hline PgaB & $\begin{array}{l}\text { Disrupts PNAG-dependent biofilms formed by B. pertussis, } \\
\text { Staphylococcus carnosus, S. epidermidis, and E. coli, through } \\
\text { hydrolyzing PNAG, a major biofilm component of many } \\
\text { pathogenic bacteria. }\end{array}$ & [118] \\
\hline Ega3 & $\begin{array}{l}\text { An endo-acting } \alpha-1,4 \text {-galactosaminidase that has been } \\
\text { demonstrated to disrupt biofilms formed by GAG-dependent } \\
\text { Aspergillus fumigatus and Pel polysaccharide-dependent } \\
\text { P. aeruginosa. }\end{array}$ & [119] \\
\hline Sph3 & $\begin{array}{l}\text { A retaining endo- } \alpha-1,4-\mathrm{N} \text {-acetylgalactosaminidase which can } \\
\text { hydrolyze galactosaminogalactan (GAG), a cationic polymer of } \\
\alpha-1,4 \text {-linked galactose and partially deacetylated } \\
\text { N-acetylgalactosamine (GalNAc) and has been demonstrated to } \\
\text { disrupt biofilms formed by A. fumigatus. }\end{array}$ & [120] \\
\hline
\end{tabular}




\subsection{Targeting Specific Components in EPS and Nucleic-Acid-Binding Proteins}

In addition to increasing bacterial resistance to antibiotics, the formation of biofilms also poses challenges to current vaccine treatments. Vaccines are specific to microorganisms; however, clinical isolates from biofilm infections show considerable variabilities in genotype and/or the phenotypic expression of vaccine-targeted epitopes [121]. To address this problem, researchers have developed antibodies that target specific EPS components, such as polysaccharide Psl, which is widely present in $P$. aeruginosa clinical isolates. Currently, monoclonal antibodies against $P$. aeruginosa-derived EPS have been identified with epitopes that bound to the polysaccharide Psl [122]. Anti-Psl antibodies have been shown to have increased opsonophagocytic killing against $P$. aeruginosa, decreased attachment to lung epithelial cells in vitro, and prophylactic protection in multiple animal models of P. aeruginosa infection.

In another experimental study, vaccine-elicited antibodies based on Enterococcus faecalis pilus tip (EbpA) effectively inhibited biofilm formation in a murine catheter-associated urinary tract infections (CAUTI) model [123]. EbpA, which functions as an adhesin, can effectively block the adhesion of E. faecalis to the catheter and inhibit biofilm formation. Notably, it has been found that EbpA did not directly mediate $E$. faecalis adhesion to the catheter material but bind to fibrinogen that deposited on the catheter surface. The results showed that wild-type E. faecalis (which expresses EbpA) was not able to adhere to the catheter in vitro and thus was unable to form biofilm, and genes required for biofilm formation in TSGB in vitro were not required in forming biofilms on catheters in vivo [124,125]. This result suggests that biofilm formation model in vitro in TSBG cannot accurately reflect the requirements for CAUTIs in vivo, which highlights the importance to use a more accurate host-microorganism model.

Targeting broadly conserved components in EPS has also been considered as desirable. The DNABII family of DNA-binding proteins, which includes integration host factor (IHF) and histone-like protein (HU), play a key role in providing structural integrity of eDNA [126]. Bacterial biofilms exposed to the antibodies that target DNABII protein will destabilize the eDNA matrix, resulting the collapse of the biofilm structure [126,127]. IHF has specifically been exploited to target nucleoproteins in biofilms due to its high binding affinity and has been widely tested in animal models [7]. Antibodies against E. coli IHF are cross-reactive that can bind to DNABII in multiple bacterial species, destabilize biofilms, and release individual bacterium. When combined immunotherapy that targets DNABII with antibiotic therapy, it can be effective against biofilms of numerous types of bacteria in murine lung infection models, including oral bacteria [128], uropathogenic E. coli [129], P. aeruginosa [127], and MRSA [130]. Another approach is to combine DNABII antibodies with vaccines. A study with nontypeable Haemophilus influenzae (NTHi) in an animal model of otitis media used IHF and recombinant soluble type IV pili (rsPilA) co-administered with an adjuvant and delivered by transcutaneous immunization to achieve early NTHi eradication and prevention of disease [131]. Recently, a "tip-chimer" immunogen to mimic the DNA-binding regions within the $\alpha$-subunit and $\beta$-subunit of IHF from NTHi $\left(\mathrm{IHF}_{\mathrm{NTHi}}\right)$ has been shown to effectively disrupt the biofilm of NTHi in an animal model of otitis media [132]. Besides, antibodies derived against the Porphyromonas gingivalis DNABII protein, HU $\beta$, reduce by half the amount of $P$. gingivalis organisms entering into preexisting biofilm formed by four oral streptococcal species, effectively dispersed oral streptococcus biofilm and prevented P. gingivalis to enter into oral streptococcus biofilm [133]. Table 5 summarizes some of the molecules that target conserved components in EPS and nucleic acid-binding proteins. 
Table 5. Targeting specific components in EPS and nucleic acid-binding proteins.

\begin{tabular}{|c|c|c|}
\hline \multicolumn{3}{|c|}{ Targeting Specific Components in EPS } \\
\hline Name & Summary & References \\
\hline Cam-003 & $\begin{array}{l}\text { A monoclonal antibody that can bind three } \\
\text { distinct epitopes on Psl, and have been } \\
\text { demonstrated to block the attachment of } P \text {. } \\
\text { aeruginosa to cultured epithelial cells, to inhibit } \\
\text { the adherence or formation of denser biofilms. }\end{array}$ & [122] \\
\hline $\mathrm{EbpA}^{\text {Full }}, \mathrm{EbpA}^{\mathrm{NTD}}$ & $\begin{array}{l}\text { Vaccine-elicited antibodies based on EbpA which } \\
\text { mediates serum antibody response, blocks the } \\
\text { interaction between EbpA and host, and inhibits } \\
\text { the formation of biofilm. }\end{array}$ & [123] \\
\hline Quadrivalent vaccine & $\begin{array}{l}\text { It is a vaccine that targets four biofilm } \\
\text { upregulated immunogens: SA0037, SA0486, } \\
\text { SA0688, and glucosaminidase. The combination } \\
\text { of quadrivalent vaccine with vancomycin can } \\
\text { significantly reduce S. aureus numbers. }\end{array}$ & [134] \\
\hline \multicolumn{3}{|c|}{ Targeting Nucleic-Acid-Binding Proteins } \\
\hline Antisera & $\begin{array}{l}\text { Antisera, which is derived against DNABII } \\
\text { proteins, has been demonstrated to be effective } \\
\text { against biofilms formed by oral bacteria, E. coli } \\
\text { and P. aeruginosa. }\end{array}$ & [127-129] \\
\hline TRL1068 & $\begin{array}{l}\text { A native human monoclonal antibody which has } \\
\text { low-picomolar affinity to DNABII homologs from } \\
\text { important Gram-positive and Gram-negative } \\
\text { bacterial pathogens, and it has been } \\
\text { demonstrated to be effective in disrupting } \\
\text { biofilms of } M R S A \text {. }\end{array}$ & [130] \\
\hline Anti-IHF $\mathrm{Ec}_{\mathrm{c}}$ & $\begin{array}{l}\text { Hyperimmune antiserum is derived against } \\
\text { purified E. coli integration host factor (IHF), and } \\
\text { has been demonstrated to be effective on biofilms } \\
\text { formed by nontypeable Haemophilus influenzae } \\
\text { (NTHi) and Burkholderia cenocepacia. }\end{array}$ & {$[126,135-137]$} \\
\hline
\end{tabular}

\section{Dispersal Molecules}

Biofilm dispersal is a regulated process involving the degradation of EPS matrix. The triggering of this response provides us a promising research strategy to promote biofilm self-disassembly. Bacteria embedded in biofilms will be more susceptible to conventional antibiotics after their returning to a planktonic state, and the released inactive cells will also lose the protection of biofilms to some degree. Regardless of dispersed state, it remains a vitally important therapy to use dispersive or exogenous EPS-degrading agents alongside systemic antibiotics to avoid recolonization or bacteremia, and potentially septicemia in clinic [7]. Herein, we divide molecules that trigger biofilm degradation into the following four groups: dispersal signals, anti-matrix molecules, sequestration molecules and metabolic interference molecules, collective called dispersal molecules. (See Table 6 for a list of various molecules.)

\subsection{Dispersal Signals}

Many key dispersal signals that can be recognized by microorganisms have been identified, such as the intracellular secondary messenger nucleotide c-di-GMP, which plays a key role in the biofilm lifecycle in both Gram-positive and Gram-negative bacteria, whereby increased levels promote biofilm formation and reduced levels promote biofilm disassembly [138]. Therefore, molecules that can bind free c-di-GMP or regulate enzymes that governing c-di-GMP levels, including diguanyl cyclases (synthesis) 
and phosphodiesterases (breakdown), are potential dispersal reagents. For example, one study used a $P$. aeruginosa construct containing an exogenous $E$. coli phosphodiesterase to show that reduction in the c-di-GMP level can be achieved via induction of YhjH c-di-GMP phosphodiesterase, which resulted in dispersal of biofilms on silicone implants in a mouse foreign body infection model [139]. Although bacteria accumulated temporarily in the spleen after the induction of biofilm dispersal, the mice were well tolerated to the dispersed bacteria. In another experiment, researchers introduced a functional protein gene PA2133 containing an EAL domain to degrade c-di-GMP into the modified system, showing that the engineered optogenetic tool inhibited the formation of P. aeruginosa biofilms and resulted in much sparser and thinner biofilms, suggesting that the synthetic optogenetic system may be a promising strategy to control and fight against biofilms [140]. Additionally, exogenous nitrate has been shown to be able to reduce the intracellular levels of c-di-GMP and inhibit the biofilm formation of Burkholderia pseudomallei 1026b [141].

Endogenously produced nitric oxide (NO) is also a kind of dispersal mediator which can be generated and recognized by both prokaryotes and eukaryotes and are highly conserved [142]. NO was first shown to regulate c-di-GMP levels, mediate biofilm dispersal in P. aeruginosa at low concentrations [143], and similar results have been reproduced in several other bacterial species [142]. Glutamate is the second molecule known to induce cells to be released from biofilms and does so in nutrient-induced dispersion process [144]. Some results suggest that biofilm dispersion under both glutamate- and NO-induced conditions may share the same mechanism [145,146]. However, gaseous NO is unstable and has potential cytotoxicity to the exposed host tissues. To address this problem, a cephalosporin-3'-diazeniumdiolates (C3Ds) NO-donor prodrug has recently been developed, which can selectively release NO from the prodrug through contacting with biofilm $\beta$-lactamases, allowing improved bacterial killing by conventional antimicrobials at sites of biofilm infections, while also minimizing NO- mediated toxicity [147]. NO-donor instability is also an issue, which is being addressed by developing sterically hindered $\mathrm{NO}$ analogues that exert biological responses via NO-mimetic properties [148]. These molecules (carboxy-TEMPO, CTMIO, DCTEIO) trigger biofilm dispersal similarly as NO in P. aeruginosa and E. coli. The treatment with carboxy-TEMPO also reduced bacteria tolerance to ciprofloxacin [148,149], however, it failed to disperse biofilms formed by MRSA, which indicates that this approach may be limited to biofilms formed by certain species [7].

\subsection{Anti-Matrix Molecules}

Another class of biofilm dispersal molecules is those that actively target the EPS matrix, also called anti-matrix molecules [6]. Prime examples of this type of molecules are rhamnolipids, which are microbial-synthesized biosurfactants that were first found to be associated with P. aeruginosa biofilms [150]. Normal concentrations of rhamnolipid are important for the maintenance of mature biofilms, particularly for fluid channel maintenance and cellular migration, but once the concentrations of rhamnoids get higher than normal levels, they will trigger a series of biofilm dispersal reactions [150-153].

An additional example of duality of surfactant function in bacterial biofilms is phenol-soluble modulins (PSMs) produced by S. aureus. PSMs are surfactant-like peptides that promote biofilm disassembly in the monomeric form by reducing the surface tension [154], however, amyloid-like fibers will be formed when they undergo orderly aggregation [155]. Polyamines, such as spermidine and norspermidine, also have a dual role. Compounds that structurally mimic norspermidine has been demonstrated to effectively inhibit the biofilm formation of Bacillus subtilis and S. aureus [156], while both spermidine and norspermidine will also induce biofilm formation in some cases [157-159]. Besides, four D-amino acids produce by bacteria, including D-tyrosine, D-leucine, D-tryptophan, and D-methionine, can destroy existing biofilms and prevent biofilm forming [160,161]. The disassembly of biofilms by D-amino acids is associated with mislocalization of a cell wall protein YqxM/TapA that anchors amyloid-like fibers to the cell wall [161,162]. D-amino acids have been proved to effectively 
work on biofilms of S. aureus, P.aeruginosa, and B.subtilis [161,163-165], and the robust effects of D-amino acids on biofilms were not associated with cytotoxicity $[161,166,167]$.

\subsection{Sequestration Molecules}

Molecules that inhibit biofilm formation by binding or interfering with other molecules involved in the production or persistence of biofilm are called sequestration molecules. These sequestration molecules may not directly act upon biofilm microbes but reduce the levels of important secondary messengers, metabolites, and nutrients, triggering active biofilm dispersal event [6]. For example, BdcA, a protein produced by E. coli that can bind free c-di-GMP, indirectly inhibiting biofilm formation by blocking the biofilm-sustaining cellular pathways and the molecule's biofilm-producing processes [168-170].

Furthermore, lactoferrin, an innate immunity protein, was shown to disrupt $P$. aeruginosa biofilm formation by sequestering Fe (III) from siderophores [171]. Iron is an essential component of many metabolically relevant proteins in living cells, and the maintenance of biofilms requires higher concentrations of iron than planktonic growth [172-174]. The functional siderophore system pyoverdin is required for biofilm maturation of P. aeruginosa, and the absence of this major iron uptake system will promote biofilm disassembly [172]. A combination of tobramycin with FDA-approved iron chelators deferoxamine or deferasirox can prevent the biofilm formation of $P$. aeruginosa on cystic fibrosis (CF) airway cells, reducing established biofilm biomass on polarized CF airway cells by approximately $90 \%$ and reducing viable bacteria in these biofilms by 7-log units [175].

\subsection{Metabolic Interference Molecules}

The potential of exogenous amino acids in the treatment of biofilms has gained great attentions. It has been proved that specific amino acids can affect both biofilm metabolism and development. For example, L-arginine (L-Arg) can modulate $\mathrm{pH}$ homeostasis within oral biofilms via neutralizing acids [176], and high concentrations of L-Arg $(>5 \mathrm{mM})$ results in dramatic reductions of Streptococcus gordonii biofilm biomass and changes biofilm architecture [177]. Treatment of polymicrobial biofilms comprised of S. mutans, S. gordonii and Actinomyces naeslundii by L-Arg can suppress S. mutans growth and results in substantial reduction in insoluble EPS and alters biofilm architecture [178]. L-Arg can destroy biofilms formed by a variety of oral microorganisms [179] and yeast cells [180]. D-arginine (D-Arg) also can work well on bacterial biofilms. It shows that D-Arg can inhibit and dissociate EPS from biofilms when its concentration exceeds $50 \mathrm{mM}$ and $100 \mathrm{mM}$, respectively, and can change the P. gingivalis biofilm structure at relatively high concentrations [181]. In addition to Arg, L-methionine (L-Met) has also been identified as a promising adjuvant to treating P. aeruginosa biofilms, which can trigger biofilm disassembly, increasing sensitivity towards ciprofloxacin in a mouse model of chronic pneumonia, and enhancing survival of infected mice [182]. Given the diversity in amino acid utilization between bacterial species, it is unlikely that a single amino acid would have a universal function, however, the importance of amino acid or bacterial metabolism in general, should not be underestimated in the development of future treatment strategies [7].

Iron metabolism also plays an important role in the biofilm formation of several pathogens [172,183-185]. As an essential nutrient, iron acquisition is crucial for pathogens to infect the host. And it has been shown that the increased of biofilm formation by P. aeruginosa was linked to increased availability of iron [186]. Host defences normally actively sequester iron to limit the growth of infecting bacteria, however, P. aeruginosa possesses multiple redundant iron receptor and uptake systems, such as production of the siderophore pyoverdin, an iron-chelating molecule [7]. Thus, molecules that are chemically similar to iron, which can be absorbed by bacteria but are not the same in its function, can be used to inhibit the iron-dependent pathways required for cell growth and biofilm formation. Transition metal gallium $(\mathrm{Ga})$ is chemical similar with Fe that can substitute for Fe in many biologic systems and inhibit Fe-dependent processes. It has been proved that Ga can inhibit biofilm formation and P. aeruginosa 
growth, kill planktonic and biofilm bacteria in vitro, and is also effective in two murine lung infection models, i.e., acute mouse pneumonia model and chronic biofilm lung infection model [187].

Table 6. Biofilm-dispersing molecules. Supplemented and modified based on information provided in [6].

\begin{tabular}{|c|c|c|}
\hline \multicolumn{3}{|c|}{ Dispersal Signals } \\
\hline Name & Summary & References \\
\hline YhjH & $\begin{array}{l}\text { E. coli phosphodiesterase that can be induced in vivo, led to } \\
\text { the reduction of c-di-GMP and dispersal of biofilms on } \\
\text { silicone implants in a mouse foreign body infection model. }\end{array}$ & [139] \\
\hline PA2133 & $\begin{array}{l}\text { A functional protein gene containing an EAL domain to } \\
\text { degrade c-di-GMP, and can inhibit biofilms formation of } \\
\text { P. aeruginosa, resulting in much sparser and thinner biofilms. }\end{array}$ & [140] \\
\hline Nitrate & $\begin{array}{l}\text { Nitrate shows the effect of reducing intracellular levels of the } \\
\text { second messenger c-di-GMP and inhibiting biofilm } \\
\text { formation of P. aeruginosa, S. aureus and } \\
\text { Burkholderia pseudomallei. }\end{array}$ & {$[141,188,189]$} \\
\hline $\mathrm{NO}$ & $\begin{array}{l}\text { An endogenously produced dispersal signal which can be } \\
\text { generated and recognized by both prokaryotes and } \\
\text { eukaryotes and are highly conserved. It has been shown to } \\
\text { be involved in the dispersal of biofilms formed by } \\
\text { P. aeruginosa, E. coli, Fusobacterium nucleatum, } \\
\text { Serratia marcescens, V. cholerae, B. licheniformis, Shewanella } \\
\text { woodyi, Neisseria gonorrhoeae, Pseudoalteromonas, Vibrio fischeri, } \\
\text { S. aureus, B. subtilis, Legionella pneumophila, } \\
\text { Nitrosomonas europaea, P. putida, C. albicans, Candida tropicalis, } \\
\text { and Ulva linza. }\end{array}$ & [142] \\
\hline Glutamate & $\begin{array}{l}\text { The second molecule known to induce the release of cells } \\
\text { from } P \text {. aeruginosa biofilms, and does so in nutrient-induced } \\
\text { dispersion process, and may share the same mechanism with } \\
\text { NO-induced biofilm dispersions. }\end{array}$ & [144-146] \\
\hline C3Ds & $\begin{array}{l}\text { A NO-donor prodrug that selectively release NO from the } \\
\text { prodrug through contacting with biofilm } \beta \text {-lactamases, } \\
\text { and allows targeted enhancement of bacterial killing by } \\
\text { conventional antimicrobials at sites of biofilm infections, } \\
\text { while also minimizing NO- mediated toxicity. It has been } \\
\text { proved to effectively disperse P. aeruginosa biofilms in vitro. }\end{array}$ & [147] \\
\hline Nitroxides & $\begin{array}{l}\text { Sterically hindered NO analogues, which exert biological } \\
\text { responses via NO-mimetic properties, and has been proved } \\
\text { to induce biofilm dispersal in P. aeruginosa and E. coli, } \\
\text { including carboxy-TEMPO, CTMIO and DCTEIO. }\end{array}$ & {$[148,149]$} \\
\hline $\begin{array}{l}\text { Cis-2-decenoic } \\
\text { acid (CDA) }\end{array}$ & $\begin{array}{l}\text { A kind of fatty acid cross-kingdom signaling molecule, also } \\
\text { known as a diffusible signal factor (DSF), which was } \\
\text { originally found to be produced by P. aeruginosa. This } \\
\text { particular DSF has been shown to trigger the dispersal of } \\
\text { biofilms formed by P. aeruginosa, E. coli, K. pneumoniae, } \\
\text { Proteus. mirabilis, S. pyogenes, B. subtilis, S. aureus, C. albicans, } \\
\text { Salmonella enterica, and S. mutans. It should be noted that } \\
\text { other DSFs, such as Burkholderia diffusible signal factor } \\
\text { (BDSF) [190] and Xanthomonas diffusible signal factor } \\
\text { (XDSF), have been isolated and exhibited similar inductions } \\
\text { of dispersal events [191]. }\end{array}$ & [192-195] \\
\hline
\end{tabular}


Table 6. Cont.

\begin{tabular}{|c|c|c|}
\hline \multicolumn{3}{|c|}{ Dispersal Signals } \\
\hline Name & Summary & References \\
\hline \multicolumn{3}{|c|}{ Anti-Matrix Molecules } \\
\hline Rhamnolipids & $\begin{array}{l}\text { A microbial-produced surfactant that, at normal levels, } \\
\text { is important for the maintenance of mature biofilms, } \\
\text { particularly for fluid channel maintenance and cellular } \\
\text { migration. At elevated levels, however, these rhamnolipids } \\
\text { have been shown to trigger the dispersal of P. aeruginosa, } \\
\text { E. coli, S. aureus, B. subtilis, M. luteus, and Yarrowia } \\
\text { lipolytica biofilms. }\end{array}$ & [150-153] \\
\hline PSM & $\begin{array}{l}\text { Surfactant-like peptides that promote biofilm disassembly in } \\
\text { their monomeric form, by reducing the surface tension, } \\
\text { but form amyloid-like fibers when they undergo } \\
\text { orderly aggregations. }\end{array}$ & {$[154,155]$} \\
\hline Polyamines & $\begin{array}{l}\text { Polyamines such as spermidine and norspermidine have } \\
\text { been proved to effectively inhibit the biofilm formation of } \\
\text { B. subtilis and S. aureus. However, in some cases both } \\
\text { spermidine and norspermidine serve as signaling molecules } \\
\text { that induce biofilm formation. }\end{array}$ & [156-159] \\
\hline D-amino acids & $\begin{array}{l}\text { D-isoforms of certain amino acids, including D-Leu, D-Met, } \\
\text { D-Trp, D-Tyr, and D-Phe, have been shown to cause the } \\
\text { disassembly of biofilms through multiple hypothesized } \\
\text { mechanisms, including (1) inhibition of genes involved in } \\
\text { EPS production; (2) incorporation of D-amino acids into the } \\
\text { bacterial cell wall, resulting in the loss of cell-surface fibers } \\
\text { which are vital to biofilm formation. D-amino acids have } \\
\text { been demonstrated to exhibit efficacy against } \text { S. aureus, } \\
\text { P. aeruginosa, and B. subtilis biofilms. }\end{array}$ & {$[161,163-165]$} \\
\hline Urea & $\begin{array}{l}\text { An amide that is theorized to break down biofilms by } \\
\text { disrupting the hydrogen bonds that are vital for EPS } \\
\text { mechanical stability, and has exhibited dispersal ability } \\
\text { against S. epidermidis, P. aeruginosa and } \\
\text { K. pneumoniae biofilms. }\end{array}$ & {$[196,197]$} \\
\hline Chitosan & $\begin{array}{l}\text { A polycationic macromolecule derived from the } \\
\text { polysaccharide chitin, and has been shown to penetrate and } \\
\text { possibly disrupt biofilms formed by Cryptococcus neoformans, } \\
\text { L. monocytogenes, P. fluorescens, Bacillus cereus, S. enterica, } \\
\text { C. albicans, and P. aeruginosa. It is important to note that it } \\
\text { has not been proved that chitosan has any direct effect on the } \\
\text { biofilm matrix, and it is possible that the molecule achieves } \\
\text { biofilm disruption by penetrating the matrix and acting on } \\
\text { the microbes themselves. }\end{array}$ & [198-202] \\
\hline \multicolumn{3}{|c|}{ Sequestration Molecules } \\
\hline BdcA & $\begin{array}{l}\text { A protein that reduces unbound c-di-GMP concentrations by } \\
\text { binding to, but not degrading, the molecules, hindering the } \\
\text { activation of biofilm-related cellular processes, and has been } \\
\text { shown to disperse biofilms formed by E. coli, P. aeruginosa, } \\
\text { P. fluorescens, and Rhizobium meliloti. }\end{array}$ & [168-170] \\
\hline EDTA & $\begin{array}{l}\text { Ethylenediaminetetraacetic acid (EDTA) is a metal-ion } \\
\text { chelator that can sequester EPS-matrix-stabilizing ions, } \\
\text { triggering biofilms dispersal of P. aeruginosa, H. influenzae, } \\
\text { S. epidermidis, C. tropicalis, and Enterococcus faecalis. }\end{array}$ & {$[203-208]$} \\
\hline
\end{tabular}


Table 6. Cont.

\begin{tabular}{|c|c|c|}
\hline \multicolumn{3}{|c|}{ Dispersal Signals } \\
\hline Name & Summary & References \\
\hline Lactoferrin & $\begin{array}{l}\text { An iron-binding protein from the innate immune system } \\
\text { which triggers active dispersal through chelating irons, } \\
\text { an essential bacterial nutrient and global regulator of a } \\
\text { variety of processes, including biofilm development and } \\
\text { growth. It has been shown to be effective against } \\
\text { P. aeruginosa, E. coli, S. aureus, E. faecalis and S. epidermidis } \\
\text { biofilms. }\end{array}$ & {$[209,210]$} \\
\hline \multicolumn{3}{|c|}{ Metabolic Interference Molecules } \\
\hline $\begin{array}{l}\text { Deferoxamine, } \\
\text { Deferasirox }\end{array}$ & $\begin{array}{l}\text { FDA-approved iron chelators that have been proved to } \\
\text { interfere with bacterial iron metabolism, preventing the } \\
\text { formation of } P \text {. aeruginosa biofilms and reducing established } \\
\text { biofilm biomass. }\end{array}$ & [175] \\
\hline L-Arg & $\begin{array}{l}\text { Exogenous amino acids can affect both biofilm metabolism } \\
\text { and development, and it has been proved that L-Arg can } \\
\text { effectively disrupt biofilm of Streptococcus gordonii and } \\
\text { S. mutans. }\end{array}$ & {$[176,178]$} \\
\hline D-Arg & $\begin{array}{l}\text { D-Arg can inhibit and dissociate EPS production from } \\
\text { biofilm and can alter the Porphyromonas gingivalis biofilm } \\
\text { structure in relatively high concentrations. }\end{array}$ & [181] \\
\hline L-Met & $\begin{array}{l}\text { L-Met can up-regulate DNase gene expression and target } \\
\text { eDNA components in biofilms. It has been proved to be } \\
\text { effective on biofilm formed by P. aeruginosa. }\end{array}$ & {$[182]$} \\
\hline $\mathrm{Ga}$ & $\begin{array}{l}\text { A transition metal that is chemically similar to Fe, thus it can } \\
\text { substitute for Fe in many biologic systems and inhibit } \\
\text { Fe-dependent processes. It was shown that Ga can inhibit } P \text {. } \\
\text { aeruginosa growth and biofilm formation and kill planktonic } \\
\text { and biofilm bacteria. }\end{array}$ & [187] \\
\hline
\end{tabular}

\section{Targeting Quorum Sensing}

Bacteria control important developmental processes by sensing and responding to environmental cues. Two widely conserved and important strategies that bacteria employ to sense changes in population density and local environmental conditions are QS and cyclic di-GMP (c-di-GMP) signaling, respectively [211]. C-di-GMP mentioned above can regulate various EPS-producing exo-enzymes, polysaccharides and adhesins, and also functions as key dispersal signals. QS enables bacteria to restrict the expression of specific genes when the population has a high cell density, resulting in phenotypes that are more beneficial. The opportunistic pathogen P. aeruginosa uses QS to coordinate the formation of biofilm, swarming motility, exopolysaccharide production, virulence, and cell aggregation [212]. These bacteria can grow within a host without detrimental effect until they reach a threshold concentration. Then, they become aggressive, developing to the point at which their numbers are sufficient to overcome the host's immune system, and form a biofilm, leading to disease within the host. QS requires the binding of a signaling molecule to its corresponding transcriptional regulator, which activates the downstream transcription of selected targets, and then the production of many virulent determinants in pathogenic bacteria which requires cell-cell communication [7]. Hence, quorum quenching, the process that prevents QS by disrupting signaling, can be achieved by (i) inhibiting the synthesis of signaling molecules, (ii) mimicking signaling molecules and binding to their receptors, (iii) degrading signaling molecules, and (iv) modifying signaling molecules. These molecules with abilities to quench the QS system called quorum sensing inhibitors (QSIs) [213].

QSIs that target the QS system in Gram-negative bacteria and Gram-positive bacteria have been extensively evaluated for their efficacy on clinically relevant bacterial biofilms using in vitro and in vivo 
models. For example, the QS autoinducer, AI-2, functions as a chemorepellent in Helicobacter pylori by regulating the proportion and spatial organization of biofilm cells, and treatment of in vitro biofilms with exogenous AI-2 resulted in both reduction in the proportion of adherent cells and induction of biofilm dispersal [214]. Some of the oils and plant extracts extracted from traditional medicinal plants include QS inhibiting compounds that can subsequently inhibit biofilms [215]. There are three types of quorum-quenching enzymes that possess abilities to degrade QS signals-acetyl homoserine lactone (AHL) acylase, AHL lactonases, and oxidoreductases [216]. The results of a published study revealed that AHL-lactonase from endophytic strain of Bacillus cereus VT96 effectively interfered with the production of AHL, thus inhibit the formation of biofilms [217].

QSIs can inhibit biofilm formation and virulence factors synthesis, while do not pose any threat to the DNA replication and cell division of the bacteria, thus chances of resistance development to such compounds are presumably rare [218]. Hence, these compounds are ideally qualified as adjunct therapeutics and could be administered along with an antibiotic to reduce chances of resistance development and also to increase the effectiveness of antimicrobial therapy [218]. However, reduced bacterial loads are often dependent on the strain and biofilm model [219]. Extensive research has been done in this area, showing that not all QS systems control biofilm formation positively [6], and the toxicity of QSIs is also an important limiting factor in its development. Thus, only a selected list of QSIs are summarized in Table 7. There are also articles that discuss the relationship between QS and c-di-GMP signaling pathways in detail and consider that QS systems can be seen as a kind of mechanism that c-di-GMP pathway used to sense environmental information-local cell density [211]. The integration of QS with c-di-GMP allows bacteria to assimilate information about the local bacterial population density with other physicochemical environmental signals within the broader c-di-GMP signaling network [211].

Table 7. Molecules that targeting quorum sensing (QS) systems.

\begin{tabular}{|c|c|c|}
\hline Name & Summary & References \\
\hline AI-2 & $\begin{array}{l}\text { QS autoinducer, functions as a chemorepellent in Helicobacter } \\
\text { pylori by regulating the proportion and spatial organization of } \\
\text { biofilm cells and has been proved to effectively reduce the } \\
\text { proportion of adherent cells and induce biofilm dispersal. }\end{array}$ & [214] \\
\hline AIP-I & $\begin{array}{l}\text { The autoinducing peptide type I activates a regulatory cascade } \\
\text { called agr system, resulting in the increased expression of } \\
\text { invasive factors, including toxins, hemolysins, proteases, and } \\
\text { other tissue-degrading enzymes. It has been proved to } \\
\text { effectively disrupt biofilm formed by MRSA. }\end{array}$ & [220] \\
\hline RIP & $\begin{array}{l}\text { RNAIII-inhibiting peptide, a heptapeptide that has been shown } \\
\text { to inhibit the biofilms formation of both methicillin-resistant and } \\
\text { vancomycin-resistant } S \text {. aureus and S. epidermidis. }\end{array}$ & [221-226] \\
\hline M64 & $\begin{array}{l}\text { A small molecule that target the MvfR-regulated QS virulence } \\
\text { pathway, which can effectively silence the MvfR communication } \\
\text { system, thus blocks P. aeruginosa virulence both in vitro and } \\
\text { in vivo. }\end{array}$ & [227] \\
\hline Cinnamic acid & $\begin{array}{l}\text { Acts as a competitive inhibitor for the natural ligands towards } \\
\text { the ligand binding domain of the transcriptional activators of } \\
\text { the quorum sensing circuit in P. aeruginosa, LasR and RhlR. It has } \\
\text { been proved to effectively inhibit both the production of the } \\
\text { QS-dependent virulence factors and biofilm formation in } \\
\text { P. aeruginosa. }\end{array}$ & [228] \\
\hline $\begin{array}{l}\text { Trans } \\
\text { 4-(2-carboxy-vinyl) } \\
\text { benzoic acid }\end{array}$ & $\begin{array}{l}\text { Cell-free extracts of Natrinema versiforme which show QSI } \\
\text { properties against } P \text {. aeruginosa and is efficient for } \\
\text { biofilm inhibition. }\end{array}$ & [229] \\
\hline SM23 & $\begin{array}{l}\text { A boronic acid derivative of } \beta \text {-lactamase inhibitor, acting as a } \\
\text { powerful inhibitor of } P \text {. aeruginosa biofilm. }\end{array}$ & [230] \\
\hline
\end{tabular}




\section{Targeting Dormant Cells in Biofilms}

Inducing biofilm active dispersal processes and antibiotic therapy both require the cells to be metabolically active, however, evidences show that dormant cells or persisters residing within biofilms play a key role for drug tolerance [7]. Antimicrobial peptides (AMPs) represent an approach to treat biofilms independent of the presence of microbial activity. AMPs is a major part of innate defense molecules against infections. According to the data from antimicrobial peptide database (APD, http://aps.unmc.edu/AP/), more than 3000 peptides with antimicrobial properties have been discovered, and 2675 of those have antibacterial activity. In recent years, some AMPs have been found to have anti-biofilm activity, which are called "anti-biofilm peptides." The first known anti-biofilm peptide is human peptide LL-37, which is able to inhibit and diminish P. aeruginosa biofilms at concentrations far below antimicrobial levels [231]. One of the most important advantages of AMPs is that they are widely conserved and therefore attractive as broad-acting antimicrobial agents that may be useful against both bacterial and fungal biofilms [232,233]. Another advantage is that AMPs target respiring cells as well as persisters and dormant populations, which may reduce the potential for bacteria to develop AMPs resistance [7]. Therefore, anti-biofilm peptides are potential therapeutic agents.

Synthetic peptides that modify specific AMP sequences have been designed and showed inhibitory activity and can enhance killing of $P$. aeruginosa biofilms in invertebrate infection models when used together with antibiotics [234]. However, microbial proteases and the binding of AMPs to EPS matrix components or other host molecules may further diminish AMPs potency [235]. To address this, combine AMPs with the approach that targets EPS matrix may further increase both the entrance and permeabilization properties of AMPs once in the biofilm [232,236]. Although using AMPs to target tolerant cells is a promising approach, remaining active post across a spatially and chemically heterogeneous microenvironment is an important challenge in vivo [7], and the high cost of AMPs synthesis is a barrier for clinical development and commercialization [236]. Beyond AMPs, antibiotics that used for the treatment of infections caused by slow-growing bacteria, such as rifampin, is an alternative strategy. When used in combination with fosfomycin, rifampin can enhance efficacy in treating foreign body MRSA biofilm infections in vivo [237]. Based on the current literature, it can be found that not all of these peptides cause biofilm dispersal by simply penetrating the EPS and killing the microbes [6]. As mentioned above for LL-37, certain peptides cause biofilm destruction at sub-MIC levels, suggesting that they are acting on the EPS, or on the microbe's ability to form or maintain a biofilm [6]. Anti-biofilm peptides have been extensively studied, so we only summarize some of them in Table 8.

In addition to the above, it is worth to mention DNA cross-linking drugs like FDA-approved anti-cancer drug mitomycin C (MMC) and cisplatin [cis-diamminodichloroplatinum(II)], which has been substantiating clinical applicability against bacterial infections. DNA cross-linking drugs mainly forms intra-strand DNA crosslinks and eradicates persister cells through a growth-independent mechanism $[238,239]$, therefore, it is very meriting investigation as a new approach for the treatment of recalcitrant infections. $\mathrm{MMC}$ is the first broad-spectrum compound capable of eliminating persister cells, passively transported and bioreductively activated leading to spontaneous cross-linking of DNA, and also worked as potent bactericide for a broad range of bacterial persisters, including commensal E. coli K-12, pathogenic species of E. coli, S. aureus and P. aeruginosa [239]. Cisplatin, which was found a little later than $\mathrm{MMC}$, can eradicate persister cells of E. coli K-12, enterohemorrhagic E. coli, S. aureus and $P$. aeruginosa, and more effective at killing P. aeruginosa persister cells than MMC; it is also highly effective against clinical isolates of $S$. aureus and $P$. aeruginosa [238]. It should be noted that some anticancer drugs may have intrinsic toxicity if used as antibacterial agents, hence, further animal tests should be performed in order to find the adequate treatment regimens and doses, and to asses if the combination of such drugs with conventional antibiotics improves bacterial clearance. This is also summarized in Table 8 . 
Table 8. Targeting dormant cells in biofilms.

\begin{tabular}{|c|c|c|}
\hline Name & Summary & References \\
\hline \multicolumn{3}{|c|}{ Anti-Biofilm Peptides } \\
\hline 1018 & $\begin{array}{l}\text { A synthetic, modified form of the cationic antimicrobial } \\
\text { peptide bactenecin, which can effectively disrupt the } \\
\text { established biofilms of P. aeruginosa, E. coli, A. baumannii, } \\
\text { K. pneumoniae, S. aureus, Salmonella typhimurium, and } \\
\text { B. cenocepacia. }\end{array}$ & {$[240,241]$} \\
\hline 17BIPHE2, GF-17 & $\begin{array}{l}\text { A } 17 \text {-amino-acid derivative of human cathelicidin LL-37 } \\
\text { which has exhibited efficacy in disrupting S. aureus biofilms. }\end{array}$ & [242] \\
\hline P60.4Ac & $\begin{array}{l}\text { A synthetic peptide derived from human cathelicidin LL-37, } \\
\text { which consists of } 24 \text { amino acids and has been shown to } \\
\text { effectively degrade biofilms formed by S. aureus. }\end{array}$ & {$[243,244]$} \\
\hline BMAP-28 & $\begin{array}{l}\text { Cathelicidin-derived peptides that can effectively degrade } \\
\text { biofilms formed by S. aureus, P. aeruginosa, } \\
\text { and Stenotrophomonas maltophilia. }\end{array}$ & {$[245,246]$} \\
\hline DJK-5, DJK-6 & $\begin{array}{l}\text { Synthetic protease-resistant peptide, D-enantiomeric, partly } \\
\text { works through degrading the (p)ppGpp bacterial stringent } \\
\text { response signal. It has been demonstrated to effectively } \\
\text { disrupt biofilm formed by P. aeruginosa, A. baumannii, } \\
\text { S. enterica and K. pneumoniae. }\end{array}$ & {$[234,247]$} \\
\hline UBBLi30 & $\begin{array}{l}\text { A kind of bacitracin produced by Bacillus paralicheniformis } \\
\text { UBBLi30 that can significantly inhibit biofilms formed by } \\
\text { M. luteus and MRSA. }\end{array}$ & [248] \\
\hline Pug-1 & $\begin{array}{l}\text { Pomegranate-derived peptides exhibit both antibacterial } \\
\text { activity and anti-adherence activity against } S \text {. mutans and } \\
\text { can inhibit the expression of virulence-associated genes and } \\
\text { enzymes. }\end{array}$ & [249] \\
\hline CSP & $\begin{array}{l}\text { Antibiofilm peptides from Capsicum baccatum (red pepper) } \\
\text { that can effectively restrict the biofilm formation by } S . \\
\text { epidermidis, without any antibiotic activity. }\end{array}$ & [250] \\
\hline GHaK, GHa4K & $\begin{array}{l}\text { Temporin-GHa (GHa) derived peptides that can effectively } \\
\text { inhibit the initial adhesion and the formation of } S \text {. aureus } \\
\text { biofilms and eradicate the mature biofilms. }\end{array}$ & [251] \\
\hline P5, P6.2 & $\begin{array}{l}\text { Two synthetic designed AMPs which have the ability to } \\
\text { interact with bacterial or eukaryotes membranes. P5 } \\
\text { displayed antibiofilm activity on both P. aeruginosa and S. } \\
\text { aureus, while P } 6.2 \text { only on S. aureus. }\end{array}$ & [252] \\
\hline B-GR23 & $\begin{array}{l}\text { A brevinin-2 like antimicrobial peptide with antimicrobial } \\
\text { activity against } S \text {. aureus, can reduce the production of EPS } \\
\text { on the planktonic growth of } S \text {. aureus and inhibit nearly all } \\
\text { planktonic bacteria to start the initial attachment of biofilm. }\end{array}$ & [253] \\
\hline \multicolumn{3}{|c|}{ DNA Cross-Linking Drugs } \\
\hline mitomycin C (MMC) & $\begin{array}{l}\text { FDA-approved anti-cancer drug, the first broad-spectrum } \\
\text { compound capable of eliminating persister cells, passively } \\
\text { transported and bioreductively activated leading to } \\
\text { spontaneous cross-linking of DNA, and also worked as } \\
\text { potent bactericide for a broad range of bacterial persisters, } \\
\text { including commensal E. coli K-12, pathogenic species of } E \text {. } \\
\text { coli, S. aureus and P. aeruginosa. }\end{array}$ & [239] \\
\hline cisplatin & $\begin{array}{l}\text { FDA-approved anti-cancer drug, } \\
\text { cis-diamminodichloroplatinum(II), can eradicates persister } \\
\text { cells of } E \text {. coli } \mathrm{K}-12 \text {, enterohemorrhagic } E \text {. coli, } S \text {. aureus and } P \text {. } \\
\text { aeruginosa, more effective at killing P. aeruginosa persister } \\
\text { cells than MMC, also highly effective against clinical isolates } \\
\text { of } \text { S. aureus and P. aeruginosa. }\end{array}$ & [238] \\
\hline
\end{tabular}




\section{Hurdles to Development}

The initiation of biofilms formation involves complex and dynamic interactions among the surface, the microorganism and the EPS. With the formation of biofilms, the adhesive strength and viscoelastic properties make the removal of a biofilm from surfaces difficult, and resident microorganisms become tolerant to antimicrobials [7]. The key point that makes biofilm difficult to remove is that using antimicrobials alone will leave residues of biofilms (including dead cells) for microbial reutilization and promoting the colonization of other microorganisms. For those dispersal agents with no antimicrobial activity, the release of planktonic cells may cause overload burden to the host immune system following a massive dispersal event. Furthermore, it has even been shown that dispersed cells may in fact be more virulent than both biofilm cells and regular planktonic cells $[254,255]$. All of these highlight the importance of complementary therapeutic strategies that target both EPS matrix and the residing microorganisms.

In addition to the problems discussed above, the ability of a drug to penetrate through existing biofilms should also be considered, as this feature may induce the de novo emergence of antimicrobial resistance owing to bacteria being subjected to sub-lethal antibiotic concentrations and affects potential cytotoxicity. One promising approach may be targeting the pathogenic microenvironment, such as acidic $\mathrm{pH}$, hypoxia, and pathogen-derived metabolites, in order to induce active biofilm dispersal in response to environmental changes. In this way, we can degrade the matrix and kill resident bacteria, eradicating the pathogenic niche with precision and minimal cytotoxicity to surrounding tissues [7].

in vivo studies and clinical trials are extremely limited with the expand of research scope on the use of dispersal agents to eradicate medical biofilms. The majority of studies were conducted in vitro on monospecies biofilms, and it is extremely difficult to extrapolate these results to more complicated, multispecies biofilms in living environments [6]. In addition, inhibitory interactions within the host environment, such as proteolytic degradation or small-molecule inhibition of therapeutic agents, as well as potential host-toxicity when utilizing proteases and other enzymes that may cause collateral damage should also be considered [6]. All of these problems make it particularly difficult to popularize dispersal agents into clinic.

Despite these limitations, research on biofilm dispersal remains a booming and promising field. Dispersal agents can target the EPS on a molecular scale or induce the microbes to actively degrade their own biofilms. Multi-targeted or combinatorial therapies is an important developing field, which may be the core to completely eliminate biofilms in the future. Understanding the potential of biofilm dispersal agents can lead to a better control of biofilm-associate diseases in clinics, as well as addressing issues such as antibiotic resistance, and applicable therapies may come into use in the near future.

\section{Conclusions}

Recurrent infections and high antibiotics/antimicrobials resistance caused by biofilms post great challenges to medical community and health field. Biofilm-associated infections are usually difficult to treat because bacteria within biofilm will be more resistant to antibiotics compared with planktonic cells, and the leftovers following antibiotic treatment will promote the colonization of other microorganisms and lead to repeated infections. Current biofilm removal approaches are purely mechanical, with very few new therapeutic options available in clinics, and it is extremely difficult to eradicate the entire biofilm infections. To address this, clinicians have combined physical-mechanical approaches, such as sharp or hydrosurgical debridement, with antibiotics or antimicrobials, in order to achieve better therapeutic effect. However, even with these interventions, some recalcitrant wounds remain difficult to heal, and antimicrobial resistances are developing. Hence, it is crucial to find novel biofilm dispersal strategies that effectively release microbes from the protection of EPS.

Dispersal agents can disrupt the EPS on a molecular scale or induce the microbes to actively degrade their own biofilms to break the protection of EPS to pathogenic bacteria, and improve the therapeutic effect to biofilm-associate infections. In this review, we discuss the current state of research regarding molecular biofilm dispersal agents from four main avenues, and we are mainly focusing on 
technologies that have shown efficacy in preclinical trials. In general, the main limitation is the paucity of clinical trials, or even in vivo studies. Thus, even though the dispersal agents are promising to be used in future medical biofilms treatments, progress needs to be made on the translating of in vitro results to the in vivo efficacy.

Author Contributions: Y.J. conceived the structure of the manuscript and wrote the manuscript; M.G. provided critical comments and revised the manuscript; L.B. reviewed and revised the manuscript. All authors have read and agreed to the published version of the manuscript.

Funding: This research was supported by grants from the CAMS Innovation Fund for Medical Sciences (2017-I2M-1-012), the National Natural Science Foundation of China (31870059), and the Drug Innovation Major Project (2018ZX09711001-007-003).

Conflicts of Interest: The authors have no relevant affiliations or financial involvement with any organization or entity with a financial interest in or financial conflict with the subject matter or materials discussed in the manuscript.

\section{References}

1. Roy, R.; Tiwari, M.; Donelli, G.; Tiwari, V. Strategies for combating bacterial biofilms: A focus on anti-biofilm agents and their mechanisms of action. Virulence 2018, 9, 522-554. [CrossRef]

2. Sharma, D.; Misba, L.; Khan, A.U. Antibiotics versus biofilm: An emerging battleground in microbial communities. Antimicrob. Resist. Infect. Control 2019, 8, 76. [CrossRef] [PubMed]

3. Flemming, H.C.; Wingender, J. The biofilm matrix. Nat. Rev. Microbiol. 2010, 8, 623-633. [CrossRef] [PubMed]

4. Rumbaugh, K.P.; Diggle, S.P.; Watters, C.M.; Ross-Gillespie, A.; Griffin, A.S.; West, S.A. Quorum Sensing and the Social Evolution of Bacterial Virulence. Curr. Biol. 2009, 19, 341-345. [CrossRef] [PubMed]

5. Karatan, E.; Watnick, P. Signals, Regulatory Networks, and Materials That Build and Break Bacterial Biofilms. Microbiol. Mol. Biol. Rev. 2009, 73, 310. [CrossRef] [PubMed]

6. Fleming, D.; Rumbaugh, K.P. Approaches to Dispersing Medical Biofilms. Microorganisms 2017, 5, 15. [CrossRef] [PubMed]

7. Koo, H.; Allan, R.N.; Howlin, R.P.; Stoodley, P.; Hall-Stoodley, L. Targeting microbial biofilms: Current and prospective therapeutic strategies. Nat. Rev. Microbiol. 2017, 15, 740-755. [CrossRef]

8. Hoiby, N.; Bjarnsholt, T.; Moser, C.; Bassi, G.L.; Coenye, T.; Donelli, G.; Hall-Stoodley, L.; Hola, V.; Imbert, C.; Kirketerp-Moller, K.; et al. ESCMID guideline for the diagnosis and treatment of biofilm infections. Clin. Microbiol. Infect. 2015, 21, S1-S25. [CrossRef]

9. Lemire, J.A.; Harrison, J.J.; Turner, R.J. Antimicrobial activity of metals: Mechanisms, molecular targets and applications. Nat. Rev. Microbiol. 2013, 11,371-384. [CrossRef]

10. Howlin, R.P.; Brayford, M.J.; Webb, J.S.; Cooper, J.J.; Aiken, S.S.; Stoodley, P. Antibiotic-loaded synthetic calcium sulfate beads for prevention of bacterial colonization and biofilm formation in periprosthetic infections. Antimicrob. Agents Chemother. 2015, 59, 111-120. [CrossRef]

11. Castaneda, P.; McLaren, A.; Tavaziva, G.; Overstreet, D. Biofilm Antimicrobial Susceptibility Increases with Antimicrobial Exposure Time. Clin. Orthop. Relat. Res. 2016, 474, 1659-1664. [CrossRef] [PubMed]

12. Fabbri, S.; Johnston, D.A.; Rmaile, A.; Gottenbos, B.; De Jager, M.; Aspiras, M.; Starke, E.M.; Ward, M.T.; Stoodley, P. Streptococcus mutans biofilm transient viscoelastic fluid behaviour during high-velocity microsprays. J. Mech. Behav. Biomed. Mater. 2016, 59, 197-206. [CrossRef] [PubMed]

13. Flemming, H.-C.; Wingender, J.; Szewzyk, U.; Steinberg, P.; Rice, S.A.; Kjelleberg, S. Biofilms: An emergent form of bacterial life. Nat. Rev. Microbiol. 2016, 14, 563-575. [CrossRef] [PubMed]

14. Hobley, L.; Harkins, C.P.; Macphee, C.E.; Stanley-Wall, N.R. Giving structure to the biofilm matrix: An overview of individual strategies and emerging common themes. FEMS Microbiol. Rev. 2015, 39, 649-669. [CrossRef]

15. Gunn, J.S.; Bakaletz, L.O.; Wozniak, D.J. What's on the Outside Matters: The Role of the Extracellular Polymeric Substance of Gram-negative Biofilms in Evading Host Immunity and as a Target for Therapeutic Intervention. J. Biol. Chem. 2016, 291, 12538-12546. [CrossRef]

16. Peng, X.; Zhang, Y.; Bai, G.; Zhou, X.; Wu, H. Cyclic di-AMP mediates biofilm formation. Mol. Microbiol. 2016, 99, 945-959. [CrossRef] 
17. Teschler, J.K.; Zamorano-Sánchez, D.; Utada, A.S.; Warner, C.J.A.; Wong, G.C.L.; Linington, R.G.; Yildiz, F. Living in the matrix: Assembly and control of Vibrio cholerae biofilms. Nat. Rev. Microbiol. 2015, 13, 255-268. [CrossRef]

18. Mann, E.E.; Wozniak, D.J. Pseudomonas biofilm matrix composition and niche biology. FEMS Microbiol. Rev. 2012, 36, 893-916. [CrossRef]

19. Ren, Z.; Cui, T.; Zeng, J.; Chen, L.; Zhang, W.; Xu, X.; Cheng, L.; Li, M.; Li, J.; Zhou, X.; et al. Molecule Targeting Glucosyltransferase Inhibits Streptococcus mutans Biofilm Formation and Virulence. Antimicrob. Agents Chemother. 2016, 60, 126-135. [CrossRef]

20. Falsetta, M.L.; Klein, M.I.; Lemos, J.A.; Bueno-Silva, B.; Agidi, S.; Scott-Anne, K.K.; Koo, H. Novel Antibiofilm Chemotherapy Targets Exopolysaccharide Synthesis and Stress Tolerance in Streptococcus mutans To Modulate Virulence Expression In Vivo. Antimicrob. Agents Chemother. 2012, 56, 6201-6211. [CrossRef]

21. Fernicola, S.; Paiardini, A.; Giardina, G.; Rampioni, G.; Leoni, L.; Cutruzzolà, F.; Rinaldo, S. In Silico Discovery and In Vitro Validation of Catechol-Containing Sulfonohydrazide Compounds as Potent Inhibitors of the Diguanylate Cyclase PleD. J. Bacteriol. 2016, 198, 147-156. [CrossRef] [PubMed]

22. Sambanthamoorthy, K.; Sloup, R.E.; Parashar, V.; Smith, J.M.; Kim, E.E.; Semmelhack, M.F.; Neiditch, M.B.; Waters, C.M. Identification of Small Molecules That Antagonize Diguanylate Cyclase Enzymes To Inhibit Biofilm Formation. Antimicrob. Agents Chemother. 2012, 56, 5202-5211. [CrossRef] [PubMed]

23. Guiton, P.S.; Cusumano, C.K.; Kline, K.A.; Dodson, K.W.; Han, Z.; Janetka, J.W.; Henderson, J.P.; Caparon, M.G.; Hultgren, S.J. Combinatorial Small-Molecule Therapy Prevents Uropathogenic Escherichia coli Catheter-Associated Urinary Tract Infections in Mice. Antimicrob. Agents Chemother. 2012, 56, 4738-4745. [CrossRef] [PubMed]

24. Totsika, M.; Kostakioti, M.; Hannan, T.; Upton, M.; Beatson, S.A.; Janetka, J.W.; Hultgren, S.J.; Schembri, M.A. A FimH inhibitor prevents acute bladder infection and treats chronic cystitis caused by multidrug-resistant uropathogenic Escherichia coli ST. J. Infect. Dis. 2013, 208, 921-928. [CrossRef]

25. Spaulding, C.N.; Klein, R.D.; Ruer, S.; Kau, A.L.; Schreiber, H.L.; Cusumano, Z.T.; Dodson, K.W.; Pinkner, J.S.; Fremont, D.H.; Janetka, J.W.; et al. Selective depletion of uropathogenic E. coli from the gut by a FimH antagonist. Nature 2017, 546, 528-532. [CrossRef]

26. Mydock-McGrane, L.; Cusumano, Z.; Han, Z.; Binkley, J.; Kostakioti, M.; Hannan, T.; Pinkner, J.S.; Klein, R.; Kalas, V.; Crowley, J.; et al. Antivirulence C-Mannosides as Antibiotic-Sparing, Oral Therapeutics for Urinary Tract Infections. J. Med. Chem. 2016, 59, 9390-9408. [CrossRef]

27. Bouckaert, J.; Berglund, J.; Schembri, M.A.; De Genst, E.; Cools, L.; Wuhrer, M.; Hung, C.-S.; Pinkner, J.; Slättegård, R.; Zavialov, A.V.; et al. Receptor binding studies disclose a novel class of high-affinity inhibitors of the Escherichia coli FimH adhesin. Mol. Microbiol. 2005, 55, 441-455. [CrossRef]

28. Han, Z.; Pinkner, J.S.; Ford, B.; Obermann, R.; Nolan, W.; Wildman, S.A.; Hobbs, D.; Ellenberger, T.; Cusumano, C.K.; Hultgren, S.J.; et al. Structure-Based Drug Design and Optimization of Mannoside Bacterial FimH Antagonists. J. Med. Chem. 2010, 53, 4779-4792. [CrossRef]

29. Cegelski, L.; Pinkner, J.S.; Hammer, N.D.; Cusumano, C.K.; Hung, C.S.; Chorell, E.; Åberg, V.; Walker, J.N.; Seed, P.C.; Almqvist, F.; et al. Small-molecule inhibitors target Escherichia coli amyloid biogenesis and biofilm formation. Nat. Methods 2009, 5, 913-919. [CrossRef]

30. Cozens, D.; Read, R.C. Anti-adhesion methods as novel therapeutics for bacterial infections. Expert Rev. Anti-Infect. Ther. 2012, 10, 1457-1468. [CrossRef]

31. Arita-Morioka, K.-I.; Yamanaka, K.; Mizunoe, Y.; Tanaka, Y.; Ogura, T.; Sugimoto, S. Inhibitory effects of Myricetin derivatives on curli-dependent biofilm formation in Escherichia coli. Sci. Rep. 2018, 8, 8452. [CrossRef] [PubMed]

32. Zhong, H.; Xie, Z.; Wei, H.; Zhang, S.; Song, Y.; Wang, M.; Zhang, Y. Antibacterial and Antibiofilm Activity of Temporin-GHc and Temporin-GHd Against Cariogenic Bacteria, Streptococcus mutans. Front. Microbiol. 2019, 10, 2854. [CrossRef] [PubMed]

33. Nett, J.E.; Cabezas-Olcoz, J.; Marchillo, K.; Mosher, D.F.; Andes, D.R. Targeting Fibronectin To Disrupt In Vivo Candida albicans Biofilms. Antimicrob. Agents Chemother. 2016, 60, 3152-3155. [CrossRef] [PubMed]

34. Singh, S.; Uppuluri, P.; Mamouei, Z.; Alqarihi, A.; Elhassan, H.; French, S.; Lockhart, S.R.; Chiller, T.; Edwards, J.E.; Ibrahim, A.S. The NDV-3A vaccine protects mice from multidrug resistant Candida auris infection. PLoS Pathog. 2019, 15, e1007460. [CrossRef] 
35. Hall-Stoodley, L.; Costerton, J.W.; Stoodley, P. Bacterial biofilms: From the Natural environment to infectious diseases. Nat. Rev. Microbiol. 2004, 2, 95-108. [CrossRef]

36. Lasa, I.; Penadés, J.R. Bap: A family of surface proteins involved in biofilm formation. Res. Microbiol. 2006, 157, 99-107. [CrossRef]

37. Jiao, Y.; Cody, G.D.; Harding, A.K.; Wilmes, P.; Schrenk, M.; Wheeler, K.E.; Banfield, J.F.; Thelen, M.P. Characterization of Extracellular Polymeric Substances from Acidophilic Microbial Biofilms. Appl. Environ. Microbiol. 2010, 76, 2916-2922. [CrossRef]

38. Muthukrishnan, G.; Quinn, G.A.; Lamers, R.P.; Diaz, C.; Cole, A.L.; Chen, S.; Cole, A.M. Exoproteome of Staphylococcus aureus Reveals Putative Determinants of Nasal Carriage. J. Proteome Res. 2011, 10, 2064-2078. [CrossRef]

39. Speziale, P.; Pietrocola, G.; Foster, T.J.; Geoghegan, J.A. Protein-based biofilm matrices in Staphylococci. Front. Cell. Infect. Microbiol. 2014, 4, 171. [CrossRef]

40. Zhang, X.; Bishop, P.L. Biodegradability of biofilm extracellular polymeric substances. Chemosphere 2003, 50, 63-69. [CrossRef]

41. Kaplan, J.B. Biofilm dispersal: Mechanisms, clinical implications, and potential therapeutic uses. J. Dent. Res. 2010, 89, 205-218. [CrossRef] [PubMed]

42. Iwase, T.; Uehara, Y.; Shinji, H.; Tajima, A.; Seo, H.; Takada, K.; Agata, T.; Mizunoe, Y. Staphylococcus epidermidis Esp inhibits Staphylococcus aureus biofilm formation and nasal colonization. Nature 2010, 465, 346-349. [CrossRef]

43. Rao, T.S.; Shukla, S.K. Staphylococcus aureus biofilm removal by targeting biofilm-associated extracellular proteins. Indian J. Med Res. 2017, 146, S1-S8. [CrossRef] [PubMed]

44. Marx, C.; Gardner, S.; Harman, R.M.; Van De Walle, G.R. The mesenchymal stromal cell secretome impairs methicillin-resistant Staphylococcus aureus biofilms via cysteine protease activity in the equine model. STEM CELLS Transl. Med. 2020, 9, 746-757. [CrossRef] [PubMed]

45. Loughran, A.J.; Atwood, D.N.; Anthony, A.C.; Harik, N.; Spencer, H.J.; Beenken, K.E.; Smeltzer, M.S. Impact of individual extracellular proteases on Staphylococcus aureus biofilm formation in diverse clinical isolates and their isogenic sarA mutants. Microbiologyopen 2014, 3, 897-909. [CrossRef] [PubMed]

46. Martí, M.; Trotonda, M.P.; Tormo-Más, M.Á.; Vergara-Irigaray, M.; Cheung, A.L.; Lasa, I.; Penadés, J.R. Extracellular proteases inhibit protein-dependent biofilm formation in Staphylococcus aureus. Microbes Infect. 2010, 12, 55-64. [CrossRef] [PubMed]

47. Gjermansen, M.; Nilsson, M.; Yang, L.; Tolker-Nielsen, T. Characterization of starvation-induced dispersion in Pseudomonas putida biofilms: Genetic elements and molecular mechanisms. Mol. Microbiol. 2010, 75, 815-826. [CrossRef]

48. Chaignon, P.; Sadovskaya, I.; Ragunah, C.; Ramasubbu, N.; Kaplan, J.B.; Jabbouri, S. Susceptibility of staphylococcal biofilms to enzymatic treatments depends on their chemical composition. Appl. Microbiol. Biotechnol. 2007, 75, 125-132. [CrossRef]

49. Cui, H.; Ma, C.; Lin, L. Co-loaded proteinase K/thyme oil liposomes for inactivation of Escherichia coli O157:H7 biofilms on cucumber. Food Funct. 2016, 7, 4030-4040. [CrossRef]

50. Fredheim, E.G.A.; Klingenberg, C.; Rohde, H.; Frankenberger, S.; Gaustad, P.; Flaegstad, T.; Sollid, J.E.; Flægstad, T. Biofilm Formation by Staphylococcus haemolyticus. J. Clin. Microbiol. 2009, 47, 1172-1180. [CrossRef]

51. Izano, E.A.; Shah, S.M.; Kaplan, J.B. Intercellular adhesion and biocide resistance in nontypeable Haemophilus influenzae biofilms. Microb. Pathog. 2009, 46, 207-213. [CrossRef] [PubMed]

52. Shukla, S.K.; Rao, T.S. Dispersal of Bap-mediated Staphylococcus aureus biofilm by proteinase K. J. Antibiot. 2013, 66, 55-60. [CrossRef] [PubMed]

53. Medina, A.A.; Kadouri, D.E. Biofilm formation of Bdellovibrio bacteriovorus host-independent derivatives. Res. Microbiol. 2009, 160, 224-231. [CrossRef] [PubMed]

54. Nguyen, U.T.; Burrows, L.L. DNase I and proteinase K impair Listeria monocytogenes biofilm formation and induce dispersal of pre-existing biofilms. Int. J. Food Microbiol. 2014, 187, 26-32. [CrossRef] [PubMed]

55. Patterson, J.L.; Girerd, P.H.; Karjane, N.W.; Jefferson, K.K. Effect of biofilm phenotype on resistance of Gardnerella vaginalis to hydrogen peroxide and lactic acid. Am. J. Obstet. Gynecol. 2007, 197, 170.e1-170.e7. [CrossRef] 
56. Boles, B.R.; Horswill, A.R. agr-Mediated Dispersal of Staphylococcus aureus Biofilms. PLoS Pathog. 2008, 4, e1000052. [CrossRef]

57. Lauderdale, K.J.; Boles, B.R.; Cheung, A.L.; Horswill, A.R. Interconnections between Sigma B, agr, and Proteolytic Activity in Staphylococcus aureus Biofilm Maturation. Infect. Immun. 2009, 77, 1623-1635. [CrossRef]

58. Mootz, J.M.; Malone, C.L.; Shaw, L.N.; Horswill, A.R. Staphopains Modulate Staphylococcus aureus Biofilm Integrity. Infect. Immun. 2013, 81, 3227-3238. [CrossRef]

59. Connolly, K.L.; Roberts, A.L.; Holder, R.C.; Reid, S.D. Dispersal of Group a Streptococcal Biofilms by the Cysteine Protease SpeB Leads to Increased Disease Severity in a Murine Model. PLoS ONE 2011, 6, e18984. [CrossRef]

60. Nelson, D.C.; Garbe, J.; Collin, M. Cysteine proteinase SpeB from Streptococcus pyogenes—A potent modifier of immunologically important host and bacterial proteins. Biol. Chem. 2011, 392, 1077-1088. [CrossRef]

61. Carothers, K.E.; Liang, Z.; Mayfield, J.; Donahue, D.L.; Lee, M.; Boggess, B.; Ploplis, V.A.; Castellino, F.J.; Lee, S.W. The Streptococcal Protease SpeB Antagonizes the Biofilms of the Human Pathogen Staphylococcus aureus USA300 through Cleavage of the Staphylococcal SdrC Protein. J. Bacteriol. 2020. [CrossRef] [PubMed]

62. Lee, S.F.; Li, Y.H.; Bowden, G.H. Detachment of Streptococcus mutans biofilm cells by an endogenous enzymatic activity. Infect. Immun. 1996, 64, 1035-1038. [CrossRef] [PubMed]

63. Banar, M.; Emaneini, M.; Satarzadeh, M.; Abdellahi, N.; Beigverdi, R.; Van Leeuwen, W.B.; Jabalameli, F. Evaluation of Mannosidase and Trypsin Enzymes Effects on Biofilm Production of Pseudomonas aeruginosa Isolated from Burn Wound Infections. PLoS ONE 2016, 11, e0164622. [CrossRef] [PubMed]

64. Niazi, S.A.; Clark, D.; Do, T.; Gilbert, S.C.; Foschi, F.; Mannocci, F.; Beighton, D. The effectiveness of enzymic irrigation in removing a nutrient-stressed endodontic multispecies biofilm. Int. Endod. J. 2014, 47, 756-768. [CrossRef]

65. McGavin, M.J.; Zahradka, C.; Rice, K.; Scott, J.E. Modification of the Staphylococcus aureus fibronectin binding phenotype by V8 protease. Infect. Immun. 1997, 65, 2621-2628. [CrossRef]

66. Whitchurch, C.B.; Tolker-Nielsen, T.; Ragas, P.C.; Mattick, J.S. Extracellular DNA Required for Bacterial Biofilm Formation. Science 2002, 295, 1487. [CrossRef]

67. Jakubovics, N.; Shields, R.; Rajarajan, N.; Burgess, J. Life after death: The critical role of extracellular DNA in microbial biofilms. Lett. Appl. Microbiol. 2013, 57, 467-475. [CrossRef]

68. Alhede, M.; Bjarnsholt, T.; Givskov, M.; Alhede, M. Pseudomonas aeruginosa biofilms: Mechanisms of immune evasion. Adv. Appl. Microbiol. 2014, 86, 1-40. [CrossRef]

69. Okshevsky, M.; Meyer, R.L. The role of extracellular DNA in the establishment, maintenance and perpetuation of bacterial biofilms. Crit. Rev. Microbiol. 2013, 41, 341-352. [CrossRef]

70. Das, T.; Sehar, S.; Manefield, M. The roles of extracellular DNA in the structural integrity of extracellular polymeric substance and bacterial biofilm development. Environ. Microbiol. Rep. 2013, 5, 778-786. [CrossRef]

71. Shak, S.; Capon, D.J.; Hellmiss, R.; Marsters, S.A.; Baker, C.L. Recombinant human DNase I reduces the viscosity of cystic fibrosis sputum. Proc. Natl. Acad. Sci. USA 1990, 87, 9188-9192. [CrossRef] [PubMed]

72. Manzenreiter, R.; Kienberger, F.; Marcos, V.; Schilcher, K.; Krautgartner, W.D.; Obermayer, A.; Huml, M.; Stoiber, W.; Hector, A.; Griese, M.; et al. Ultrastructural characterization of cystic fibrosis sputum using atomic force and scanning electron microscopy. J. Cyst. Fibros. 2012, 11, 84-92. [CrossRef] [PubMed]

73. Fujihara, J.; Yasuda, T.; Kunito, T.; Fujii, Y.; Takatsuka, H.; Moritani, T.; Takeshita, H. Two N-Linked Glycosylation Sites (Asn18 and Asn106) Are Both Required for Full Enzymatic Activity, Thermal Stability, and Resistance to Proteolysis in Mammalian Deoxyribonuclease I. Biosci. Biotechnol. Biochem. 2008, 72, 3197-3205. [CrossRef] [PubMed]

74. Okshevsky, M.; Regina, V.R.; Meyer, R.L. Extracellular DNA as a target for biofilm control. Curr. Opin. Biotechnol. 2015, 33, 73-80. [CrossRef] [PubMed]

75. Chen, C.-Y.; Lu, S.-C.; Liao, T.-H. Cloning, sequencing and expression of a cDNA encoding bovine pancreatic deoxyribonuclease I in Escherichia coli: Purification and characterization of the recombinant enzyme. Gene 1998, 206, 181-184. [CrossRef]

76. Demain, A.L.; Vaishnav, P. Production of recombinant proteins by microbes and higher organisms. Biotechnol. Adv. 2009, 27, 297-306. [CrossRef] 
77. Cho, E.-S.; Kim, J.-H.; Yoon, K.-H.; Kim, Y.H.; Nam, S.W. Overexpression and Characterization of Bovine Pancreatic Deoxyribonuclease I in Saccharomyces cerevisiae and Pichia pastoris. Microbiol. Biotechnol. Lett. 2012, 40, 348-355. [CrossRef]

78. Hymes, S.; Randis, T.M.; Sun, T.Y.; Ratner, A.J. DNase Inhibits Gardnerella vaginalis Biofilms In Vitro and In Vivo. J. Infect. Dis. 2013, 207, 1491-1497. [CrossRef]

79. Qin, Z.; Ou, Y.; Yang, L.; Zhu, Y.; Tolker-Nielsen, T.; Molin, S.; Qu, D. Role of autolysin-mediated DNA release in biofilm formation of Staphylococcus epidermidis. Microbiology 2007, 153, 2083-2092. [CrossRef]

80. Seper, A.; Fengler, V.H.; Roier, S.; Wolinski, H.; Kohlwein, S.D.; Bishop, A.L.; Camilli, A.; Reidl, J.; Schild, S. Extracellular nucleases and extracellular DNA play important roles in Vibrio cholerae biofilm formation. Mol. Microbiol. 2011, 82, 1015-1037. [CrossRef]

81. Eckhart, L.; Fischer, H.; Barken, K.; Tolker-Nielsen, T.; Tschachler, E. DNase1L2 suppresses biofilm formation by Pseudomonas aeruginosa and Staphylococcus aureus. Br. J. Dermatol. 2007, 156, 1342-1345. [CrossRef] [PubMed]

82. Hall-Stoodley, L.; Nistico, L.; Sambanthamoorthy, K.; Dice, B.; Nguyen, D.; Mershon, W.J.; Johnson, C.; Hu, F.Z.; Stoodley, P.; Ehrlich, G.D.; et al. Characterization of biofilm matrix, degradation by DNase treatment and evidence of capsule downregulation in Streptococcus pneumoniae clinical isolates. BMC Microbiol. 2008, 8, 173. [CrossRef] [PubMed]

83. Kaplan, J.B.; LoVetri, K.; Cardona, S.T.; Madhyastha, S.; Sadovskaya, I.; Jabbouri, S.; Izano, E.A. Recombinant human DNase I decreases biofilm and increases antimicrobial susceptibility in staphylococci. J. Antibiot. 2011, 65, 73-77. [CrossRef] [PubMed]

84. Nijland, R.; Hall, M.; Burgess, J.G. Dispersal of Biofilms by Secreted, Matrix Degrading, Bacterial DNase. PLOS ONE 2010, 5, e15668. [CrossRef]

85. Shakir, A.; ElBadawey, M.R.; Shields, R.; Jakubovics, N.; Burgess, J.G. Removal of Biofilms from Tracheoesophageal Speech Valves Using a Novel Marine Microbial Deoxyribonuclease. Otolaryngol. Head Neck Surg. 2012, 147, 509-514. [CrossRef]

86. Shields, R.; Mokhtar, N.; Ford, M.; Hall, M.; Burgess, J.G.; ElBadawey, M.R.; Jakubovics, N. Efficacy of a Marine Bacterial Nuclease against Biofilm Forming Microorganisms Isolated from Chronic Rhinosinusitis. PLoS ONE 2013, 8, e55339. [CrossRef]

87. Nemoto, K.; Hirota, K.; Murakami, K.; Taniguti, K.; Murata, H.; Viducic, D.; Miyake, Y. Effect of Varidase (streptodornase) on biofilm formed by Pseudomonas aeruginosa. Chemotherapy 2003, 49, 121-125. [CrossRef]

88. Bales, P.M.; Renke, E.M.; May, S.L.; Shen, Y.; Nelson, D.C. Purification and Characterization of Biofilm-Associated EPS Exopolysaccharides from ESKAPE Organisms and Other Pathogens. PLoS ONE 2013, 8, e67950. [CrossRef]

89. Wingender, J.; Strathmann, M.; Rode, A.; Leis, A.; Flemming, H.-C. [25] Isolation and biochemical characterization of extracellular polymeric substances from Pseudomonas aeruginosa. Methods Enzymol. 2001, 336, 302-314. [CrossRef]

90. Limoli, D.H.; Jones, C.J.; Wozniak, D.J. Bacterial Extracellular Polysaccharides in Biofilm Formation and Function. Microbiol. Spectr. 2015, 3, 223-247. [CrossRef]

91. Watters, C.; Fleming, D.; Bishop, D.; Rumbaugh, K. Host Responses to Biofilm. Prog. Mol. Biol. Transl. Sci. 2016, 142, 193-239. [CrossRef]

92. Pestrak, M.J.; Baker, P.; Dellos-Nolan, S.; Hill, P.J.; Da Silva, D.P.; Silver, H.; Lacdao, I.; Raju, D.; Parsek, M.R.; Wozniak, D.J.; et al. Treatment with the Pseudomonas aeruginosa Glycoside Hydrolase PslG Combats Wound Infection by Improving Antibiotic Efficacy and Host Innate Immune Activity. Antimicrob. Agents Chemother. 2019, 63. [CrossRef] [PubMed]

93. Pleszczyńska, M.; Wiater, A.; Janczarek, M.; Szczodrak, J. (1 $\rightarrow 3)-\alpha-d-G l u c a n$ hydrolases in dental biofilm prevention and control: A review. Int. J. Biol. Macromol. 2015, 79, 761-778. [CrossRef]

94. Fleming, D.; Chahin, L.; Rumbaugh, K.P. Glycoside Hydrolases Degrade Polymicrobial Bacterial Biofilms in Wounds. Antimicrob. Agents Chemother. 2016, 61. [CrossRef] [PubMed]

95. Kaplan, J.B. Biofilm Matrix-Degrading Enzymes. In Microbial Biofilms; Humana Press: New York, NY, USA, 2014; Volume 1147, pp. 203-213. [CrossRef] 
96. Schmelcher, M.; Shen, Y.; Nelson, D.C.; Eugster, M.R.; Eichenseher, F.; Hanke, D.C.; Loessner, M.J.; Dong, S.; Pritchard, D.G.; Lee, J.C.; et al. Evolutionarily distinct bacteriophage endolysins featuring conserved peptidoglycan cleavage sites protect mice from MRSA infection. J. Antimicrob. Chemother. 2015, 70, 1453-1465. [CrossRef] [PubMed]

97. Becker, S.C.; Roach, D.R.; Chauhan, V.S.; Shen, Y.; Foster-Frey, J.; Powell, A.M.; Bauchan, G.R.; Lease, R.A.; Mohammadi, H.; Harty, W.J.; et al. Triple-acting Lytic Enzyme Treatment of Drug-Resistant and Intracellular Staphylococcus aureus. Sci. Rep. 2016, 6, 25063. [CrossRef] [PubMed]

98. Kimura, Y.; Hess, D.; Sturm, A. The N-glycans of jack bean alpha-mannosidase. Structure, topology and function. JBIC J. Biol. Inorg. Chem. 1999, 264, 168-175. [CrossRef] [PubMed]

99. McCleary, B.V.; Matheson, N.K. Action patterns and substrate-binding requirements of $\beta$-d-mannanase with mannosaccharides and mannan-type polysaccharides. Carbohydr. Res. 1983, 119, 191-219. [CrossRef]

100. Alkawash, M.A.; Soothill, J.S.; Schiller, N.L. Alginate lyase enhances antibiotic killing of mucoid Pseudomonas aeruginosa in biofilms. Apmis 2006, 114, 131-138. [CrossRef]

101. Bayer, A.S.; Speert, D.P.; Park, S.; Tu, J.; Witt, M.; Nast, C.C.; Norman, D.C. Functional role of mucoid exopolysaccharide (alginate) in antibiotic-induced and polymorphonuclear leukocyte-mediated killing of Pseudomonas aeruginosa. Infect. Immun. 1991, 59, 302-308. [CrossRef]

102. Hisano, T.; Nishimura, M.; Yonemoto, Y.; Abe, S.; Yamashita, T.; Sakaguchi, K.; Kimura, A.; Murata, K. Bacterial alginate lyase highly active on acetylated alginates. J. Ferment. Bioeng. 1993, 75, 332-335. [CrossRef]

103. Lamppa, J.W.; Griswold, K.E. Alginate Lyase Exhibits Catalysis-Independent Biofilm Dispersion and Antibiotic Synergy. Antimicrob. Agents Chemother. 2013, 57, 137-145. [CrossRef] [PubMed]

104. Bradford, C.; Craigen, B.; Dashiff, A.; Kadouri, D.K. The Use of Commercially Available Alpha-Amylase Compounds to Inhibit and Remove Staphylococcus aureus Biofilms. Open Microbiol. J. 2011, 5, 21-31. [CrossRef] [PubMed]

105. Kalpana, B.J.; Aarthy, S.; Pandian, S.K. Antibiofilm Activity of $\alpha$-Amylase from Bacillus subtilis S8-18 Against Biofilm Forming Human Bacterial Pathogens. Appl. Biochem. Biotechnol. 2012, 167, 1778-1794. [CrossRef]

106. Millenbaugh, N.J.; Watters, C.M.; Burton, T.; Kirui, D.K. Enzymatic degradation of in vitro Staphylococcus aureus biofilms supplemented with human plasma. Infect. Drug Resist. 2016, 9, 71-78. [CrossRef]

107. Fazekas, E.; Kandra, L.; Gyémánt, G. Model for $\beta-1$, 6-N-acetylglucosamine oligomer hydrolysis catalysed by DispersinB, a biofilm degrading enzyme. Carbohydr. Res. 2012, 363, 7-13. [CrossRef]

108. Gawande, P.V.; Leung, K.P.; Madhyastha, S. Antibiofilm and Antimicrobial Efficacy of DispersinBß-KSL-W Peptide-Based Wound Gel Against Chronic Wound Infection Associated Bacteria. Curr. Microbiol. 2014, 68, 635-641. [CrossRef]

109. Itoh, Y.; Wang, X.; Hinnebusch, B.J.; Preston, J.F.; Romeo, T. Depolymerization of $\beta-1$, 6-N-Acetyl-d-Glucosamine Disrupts the Integrity of Diverse Bacterial Biofilms. J. Bacteriol. 2005, 187, 382-387. [CrossRef]

110. Izano, E.A.; Sadovskaya, I.; Vinogradov, E.V.; Mulks, M.H.; Velliyagounder, K.; Ragunath, C.; Kher, W.B.; Ramasubbu, N.; Jabbouri, S.; Perry, M.B.; et al. Poly-N-acetylglucosamine mediates biofilm formation and antibiotic resistance in Actinobacillus pleuropneumoniae. Microb. Pathog. 2007, 43, 1-9. [CrossRef]

111. Izano, E.; Wang, H.; Ragunath, C.; Ramasubbu, N.; Kaplan, J.; Bos, T.V.D.; Handoko, G.; Niehof, A.; Ryan, L.; Coburn, S.; et al. Detachment and Killing of Aggregatibacter actinomycetemcomitans Biofilms by Dispersin B and SDS. J. Dent. Res. 2007, 86, 618-622. [CrossRef]

112. Kaplan, J.B.; Ragunath, C.; Velliyagounder, K.; Fine, D.H.; Ramasubbu, N. Enzymatic Detachment of Staphylococcus epidermidis Biofilms. Antimicrob. Agents Chemother. 2004, 48, 2633-2636. [CrossRef] [PubMed]

113. Waryah, C.; Wells, K.; Ulluwishewa, D.; Chen-Tan, N.; Gogoi-Tiwari, J.; Ravensdale, J.T.; Costantino, P.; Gökçen, A.; Vilcinskas, A.; Wiesner, J.; et al. In Vitro Antimicrobial Efficacy of Tobramycin Against Staphylococcus aureus Biofilms in Combination With or Without DNase I and/or Dispersin B: A Preliminary Investigation. Microb. Drug Resist. 2017, 23, 384-390. [CrossRef] [PubMed]

114. Yakandawala, N.; Gawande, P.V.; LoVetri, K.; Cardona, S.T.; Romeo, T.; Nitz, M.; Madhyastha, S. Characterization of the Poly- $\beta-1,6-\mathrm{N}-$ Acetylglucosamine Polysaccharide Component of Burkholderia Biofilms. Appl. Environ. Microbiol. 2011, 77, 8303-8309. [CrossRef] [PubMed]

115. Ibberson, C.B.; Parlet, C.P.; Kwiecinski, J.; Crosby, H.A.; Meyerholz, D.K.; Horswill, A.R. Hyaluronan Modulation Impacts Staphylococcus aureus Biofilm Infection. Infect. Immun. 2016, 84, 1917-1929. [CrossRef] [PubMed] 
116. Pecharki, D.; Petersen, F.C.; Scheie, A.A. Role of hyaluronidase in Streptococcus intermedius biofilm. Microbiology 2008, 154, 932-938. [CrossRef]

117. Baker, P.; Hill, P.J.; Snarr, B.D.; Alnabelseya, N.; Pestrak, M.J.; Lee, M.J.; Jennings, L.K.; Tam, J.; Melnyk, R.A.; Parsek, M.R.; et al. Exopolysaccharide biosynthetic glycoside hydrolases can be utilized to disrupt and prevent Pseudomonas aeruginosa biofilms. Sci. Adv. 2016, 2, e1501632. [CrossRef]

118. Little, D.J.; Pfoh, R.; Le Mauff, F.; Bamford, N.C.; Notte, C.; Baker, P.; Guragain, M.; Robinson, H.; Pier, G.B.; Nitz, M.; et al. PgaB orthologues contain a glycoside hydrolase domain that cleaves deacetylated poly- $\beta(1,6)-\mathrm{N}$-acetylglucosamine and can disrupt bacterial biofilms. PLoS Pathog. 2018, 14, e1006998. [CrossRef]

119. Bamford, N.C.; Le Mauff, F.; Subramanian, A.S.; Yip, P.; Millán, C.; Zhang, Y.; Zacharias, C.; Forman, A.; Nitz, M.; Codée, J.D.C.; et al. Ega3 from the fungal pathogen Aspergillus fumigatus is an endo- $\alpha$-1,4-galactosaminidase that disrupts microbial biofilms. J. Biol. Chem. 2019, 294, 13833-13849. [CrossRef]

120. Le Mauff, F.; Bamford, N.C.; Alnabelseya, N.; Zhang, Y.; Baker, P.; Robinson, H.; Codée, J.D.C.; Howell, P.L.; Sheppard, D.C. Molecular mechanism of Aspergillus fumigatus biofilm disruption by fungal and bacterial glycoside hydrolases. J. Biol. Chem. 2019, 294, 10760-10772. [CrossRef]

121. Bhattacharya, M.; Wozniak, D.J.; Stoodley, P.; Hall-Stoodley, L. Prevention and treatment of Staphylococcus aureus biofilms. Expert Rev. Anti-Infect. Ther. 2015, 13, 1499-1516. [CrossRef]

122. DiGiandomenico, A.; Warrener, P.; Hamilton, M.; Guillard, S.; Ravn, P.; Minter, R.; Camara, M.M.; Venkatraman, V.; MacGill, R.S.; Lin, J.; et al. Identification of broadly protective human antibodies to Pseudomonas aeruginosa exopolysaccharide Psl by phenotypic screening. J. Exp. Med. 2012, 209, 1273-1287. [CrossRef] [PubMed]

123. Flores-Mireles, A.L.; Pinkner, J.S.; Caparon, M.G.; Hultgren, S.J. EbpA vaccine antibodies block binding of Enterococcus faecalis to fibrinogen to prevent catheter-associated bladder infection in mice. Sci. Transl. Med. 2014, 6, 254ra127. [CrossRef] [PubMed]

124. Guiton, P.S.; Hung, C.S.; Hancock, L.E.; Caparon, M.G.; Hultgren, S.J. Enterococcal Biofilm Formation and Virulence in an Optimized Murine Model of Foreign Body-Associated Urinary Tract Infections. Infect. Immun. 2010, 78, 4166-4175. [CrossRef] [PubMed]

125. Guiton, P.S.; Hung, C.S.; Kline, K.A.; Roth, R.; Kau, A.L.; Hayes, E.; Heuser, J.; Dodson, K.W.; Caparon, M.G.; Hultgren, S.J. Contribution of Autolysin and Sortase A during Enterococcus faecalis DNA-Dependent Biofilm Development. Infect. Immun. 2009, 77, 3626-3638. [CrossRef]

126. Goodman, S.D.; Obergfell, K.P.; Jurcisek, J.A.; Novotny, L.A.; Downey, J.S.; Ayala, E.A.; Tjokro, N.; Li, B.; Justice, S.S.; Bakaletz, L.O. Biofilms can be dispersed by focusing the immune system on a common family of bacterial nucleoid-associated proteins. Mucosal Immunol. 2011, 4, 625-637. [CrossRef] [PubMed]

127. Novotny, L.A.; Jurcisek, J.A.; Goodman, S.D.; Bakaletz, L.O. Monoclonal antibodies against DNA-binding tips of DNABII proteins disrupt biofilms in vitro and induce bacterial clearance in vivo. EBioMedicine 2016, 10, 33-44. [CrossRef]

128. Rocco, C.J.; Davey, M.E.; Bakaletz, L.O.; Goodman, S.D. Natural antigenic differences in the functionally equivalent extracellular DNABII proteins of bacterial biofilms provide a means for targeted biofilm therapeutics. Mol. Oral Microbiol. 2016, 32, 118-130. [CrossRef]

129. Devaraj, A.; Justice, S.S.; Bakaletz, L.O.; Goodman, S.D. DNABII proteins play a central role in UPEC biofilm structure. Mol. Microbiol. 2015, 96, 1119-1135. [CrossRef]

130. Estellés, A.; Woischnig, A.-K.; Liu, K.; Stephenson, R.; Lomongsod, E.; Nguyen, D.; Zhang, J.; Heidecker, M.; Yang, Y.; Simon, R.J.; et al. A High-Affinity Native Human Antibody Disrupts Biofilm from Staphylococcus aureus Bacteria and Potentiates Antibiotic Efficacy in a Mouse Implant Infection Model. Antimicrob. Agents Chemother. 2016, 60, 2292-2301. [CrossRef]

131. Novotny, L.A.; Jurcisek, J.A.; Ward, M.O.; Jordan, Z.B.; Goodman, S.D.; Bakaletz, L.O. Antibodies against the majority subunit of type IV Pili disperse nontypeable Haemophilus influenzae biofilms in a LuxS-dependent manner and confer therapeutic resolution of experimental otitis media. Mol. Microbiol. 2015, 96, 276-292. [CrossRef]

132. Novotny, L.A.; Goodman, S.D.; Bakaletz, L.O. Redirecting the immune response towards immunoprotective domains of a DNABII protein resolves experimental otitis media. Npj Vaccines 2019, 4, 1-12. [CrossRef] [PubMed] 
133. Rocco, C.J.; Bakaletz, L.O.; Goodman, S.D. Targeting the HU $\beta$ Protein Prevents Porphyromonas gingivalis from Entering into Preexisting Biofilms. J. Bacteriol. 2018, 200. [CrossRef] [PubMed]

134. Brady, R.A.; O'May, G.A.; Leid, J.G.; Prior, M.L.; Costerton, J.W.; Shirtliff, M.E. Resolution of Staphylococcus aureus Biofilm Infection Using Vaccination and Antibiotic Treatment. Infect. Immun. 2011, 79, 1797-1803. [CrossRef]

135. Brockson, M.E.; Novotny, L.A.; Mokrzan, E.M.; Malhotra, S.; Jurcisek, J.A.; Akbar, R.; Devaraj, A.; Goodman, S.D.; Bakaletz, L.O. Evaluation of the kinetics and mechanism of action of anti-integration host factor-mediated disruption of bacterial biofilms. Mol. Microbiol. 2014, 93, 1246-1258. [CrossRef] [PubMed]

136. Freire, M.; Devaraj, A.; Young, A.; Navarro, J.; Downey, J.; Chen, C.; Bakaletz, L.; Zadeh, H.; Goodman, S.D. A bacterial-biofilm-induced oral osteolytic infection can be successfully treated by immuno-targeting an extracellular nucleoid-associated protein. Mol. Oral Microbiol. 2017, 32, 74-88. [CrossRef] [PubMed]

137. Novotny, L.A.; Amer, A.O.; Brockson, M.E.; Goodman, S.D.; Bakaletz, L.O. Structural Stability of Burkholderia cenocepacia Biofilms Is Reliant on eDNA Structure and Presence of a Bacterial Nucleic Acid Binding Protein. PLoS ONE 2013, 8, e67629. [CrossRef]

138. McDougald, D.; Rice, S.A.; Barraud, N.; Steinberg, P.D.; Kjelleberg, S. Should we stay or should we go: Mechanisms and ecological consequences for biofilm dispersal. Nat. Rev. Microbiol. 2011, 10, 39-50. [CrossRef]

139. Christensen, L.D.; Van Gennip, M.; Rybtke, M.T.; Wu, H.; Chiang, W.-C.; Alhede, M.; Høiby, N.; Nielsen, T.E.; Givskov, M.; Tolker-Nielsen, T. Clearance of Pseudomonas aeruginosa Foreign-Body Biofilm Infections through Reduction of the Cyclic Di-GMP Level in the Bacteria. Infect. Immun. 2013, 81, 2705-2713. [CrossRef]

140. Pu, L.; Yang, S.; Xia, A.; Jin, F. Optogenetics Manipulation Enables Prevention of Biofilm Formation of Engineered Pseudomonas aeruginosa on Surfaces. ACS Synth. Biol. 2018, 7, 200-208. [CrossRef]

141. Mangalea, M.R.; Plumley, B.A.; Borlee, B.R. Nitrate Sensing and Metabolism Inhibit Biofilm Formation in the Opportunistic Pathogen Burkholderia pseudomallei by Reducing the Intracellular Concentration of c-di-GMP. Front. Microbiol. 2017, 8, 1353. [CrossRef]

142. Barraud, N.; Kelso, M.; Rice, S.; Kjelleberg, S. Nitric Oxide: A Key Mediator of Biofilm Dispersal with Applications in Infectious Diseases. Curr. Pharm. Des. 2014, 21, 31-42. [CrossRef] [PubMed]

143. Barraud, N.; Schleheck, D.; Klebensberger, J.; Webb, J.S.; Hassett, D.J.; Rice, S.A.; Kjelleberg, S. Nitric Oxide Signaling in Pseudomonas aeruginosa Biofilms Mediates Phosphodiesterase Activity, Decreased Cyclic Di-GMP Levels, and Enhanced Dispersal. J. Bacteriol. 2009, 191, 7333-7342. [CrossRef] [PubMed]

144. Sauer, K.; Cullen, M.C.; Rickard, A.H.; Zeef, L.A.H.; Davies, D.G.; Gilbert, P. Characterization of Nutrient-Induced Dispersion in Pseudomonas aeruginosa PAO1 Biofilm. J. Bacteriol. 2004, 186, 7312-7326. [CrossRef] [PubMed]

145. Ha, D.-G.; O’Toole, G.A. c-di-GMP and its Effects on Biofilm Formation and Dispersion: A Pseudomonas Aeruginosa Review. Microbiol. Spectr. 2015, 3, 301-317. [CrossRef]

146. Roy, A.B.; Petrova, O.E.; Sauer, K. The Phosphodiesterase DipA (PA5017) Is Essential for Pseudomonas aeruginosa Biofilm Dispersion. J. Bacteriol. 2012, 194, 2904-2915. [CrossRef]

147. Barraud, N.; Kardak, B.G.; Yepuri, N.R.; Howlin, R.P.; Webb, J.S.; Faust, S.N.; Kjelleberg, S.; Rice, S.A.; Kelso, M.J. Cephalosporin-3'-diazeniumdiolates: Targeted NO-Donor Prodrugs for Dispersing Bacterial Biofilms. Angew. Chem. Int. Ed. 2012, 51, 9057-9060. [CrossRef]

148. De La Fuente-Núñez, C.; Reffuveille, F.; Fairfull-Smith, K.E.; Hancock, R.E.W. Effect of Nitroxides on Swarming Motility and Biofilm Formation, Multicellular Behaviors in Pseudomonas aeruginosa. Antimicrob. Agents Chemother. 2013, 57, 4877-4881. [CrossRef]

149. Reffuveille, F.; De La Fuente-Nunez, C.; Fairfull-Smith, K.E.; Hancock, R.E.W. Potentiation of ciprofloxacin action against Gram-negative bacterial biofilms by a nitroxide. Pathog. Dis. 2015, 73. [CrossRef]

150. Boles, B.R.; Thoendel, M.; Singh, P.K. Rhamnolipids mediate detachment of Pseudomonas aeruginosa from biofilms. Mol. Microbiol. 2005, 57, 1210-1223. [CrossRef]

151. Bhattacharjee, A.; Nusca, T.D.; Hochbaum, A.I. Rhamnolipids Mediate an Interspecies Biofilm Dispersal Signaling Pathway. ACS Chem. Biol. 2016, 11, 3068-3076. [CrossRef]

152. De Rienzo, M.D.; Martin, P.J. Effect of Mono and Di-rhamnolipids on Biofilms Pre-formed by Bacillus subtilis BBK006. Curr. Microbiol. 2016, 73, 183-189. [CrossRef] [PubMed] 
153. Quinn, G.A.; Maloy, A.P.; Banat, M.M.; Banat, I.M. A Comparison of Effects of Broad-Spectrum Antibiotics and Biosurfactants on Established Bacterial Biofilms. Curr. Microbiol. 2013, 67, 614-623. [CrossRef] [PubMed]

154. Periasamy, S.; Joo, H.-S.; Duong, A.C.; Bach, T.-H.L.; Tan, V.Y.; Chatterjee, S.S.; Cheung, G.Y.C.; Otto, M. How Staphylococcus aureus biofilms develop their characteristic structure. Proc. Natl. Acad. Sci. USA 2012, 109, 1281-1286. [CrossRef] [PubMed]

155. Schwartz, K.; Syed, A.K.; Stephenson, R.E.; Rickard, A.H.; Boles, B.R. Functional Amyloids Composed of Phenol Soluble Modulins Stabilize Staphylococcus aureus Biofilms. PLoS Pathog. 2012, 8, e1002744. [CrossRef]

156. Böttcher, T.; Kolodkin-Gal, I.; Kolter, R.; Losick, R.; Clardy, J. Synthesis and Activity of Biomimetic Biofilm Disruptors. J. Am. Chem. Soc. 2013, 135, 2927-2930. [CrossRef]

157. Burrell, M.; Hanfrey, C.C.; Murray, E.J.; Stanley-Wall, N.R.; Michael, A.J. Evolution and Multiplicity of Arginine Decarboxylases in Polyamine Biosynthesis and Essential Role in Bacillus subtilis Biofilm Formation. J. Biol. Chem. 2010, 285, 39224-39238. [CrossRef]

158. Karatan, E.; Duncan, T.R.; Watnick, P.I. NspS, a Predicted Polyamine Sensor, Mediates Activation of Vibrio cholerae Biofilm Formation by Norspermidine. J. Bacteriol. 2005, 187, 7434-7443. [CrossRef]

159. Li, B.; Maezato, Y.; Kim, S.H.; Kurihara, S.; Liang, J.; Michael, A.J. Polyamine-independent growth and biofilm formation, and functional spermidine/spermine $\mathrm{N}$-acetyltransferases in Staphylococcus aureus and Enterococcus faecalis. Mol. Microbiol. 2018, 111, 159-175. [CrossRef]

160. Hochbaum, A.I.; Kolodkin-Gal, I.; Foulston, L.; Kolter, R.; Aizenberg, J.; Losick, R. Inhibitory Effects of D-Amino Acids on Staphylococcus aureus Biofilm Development. J. Bacteriol. 2011, 193, 5616-5622. [CrossRef]

161. Kolodkin-Gal, I.; Romero, D.; Cao, S.; Clardy, J.; Kolter, R.; Losick, R.; Kolodkin-Gal, I.; Kolodkin-Gal, I. D-Amino Acids Trigger Biofilm Disassembly. Science 2010, 328, 627-629. [CrossRef]

162. Romero, D.; Vlamakis, H.; Losick, R.; Kolter, R. An accessory protein required for anchoring and assembly of amyloid fibres in B. subtilis biofilms. Mol. Microbiol. 2011, 80, 1155-1168. [CrossRef] [PubMed]

163. Harmata, A.J.; Ma, Y.; Sanchez, C.J.; Zienkiewicz, K.J.; Elefteriou, F.; Wenke, J.C.; Guelcher, S.A. d-amino Acid Inhibits Biofilm but not New Bone Formation in an Ovine Model. Clin. Orthop. Relat. Res. 2015, 473, 3951-3961. [CrossRef]

164. Leiman, S.A.; May, J.M.; Lebar, M.D.; Kahne, D.; Kolter, R.; Losick, R. D-Amino Acids Indirectly Inhibit Biofilm Formation in Bacillus subtilis by Interfering with Protein Synthesis. J. Bacteriol. 2013, 195, 5391-5395. [CrossRef]

165. Sanchez, C.J.; Akers, K.S.; Romano, D.R.; Woodbury, R.L.; Hardy, S.K.; Murray, C.K.; Wenke, J.C. d-Amino Acids Enhance the Activity of Antimicrobials against Biofilms of Clinical Wound Isolates of Staphylococcus aureus and Pseudomonas aeruginosa. Antimicrob. Agents Chemother. 2014, 58, 4353-4361. [CrossRef]

166. Sanchez, C.J.; Prieto, E.M.; Krueger, C.A.; Zienkiewicz, K.J.; Romano, D.R.; Ward, C.L.; Akers, K.S.; Guelcher, S.A.; Wenke, J.C. Effects of local delivery of d-amino acids from biofilm-dispersive scaffolds on infection in contaminated rat segmental defects. Biomaterials 2013, 34, 7533-7543. [CrossRef]

167. Yu, C.; Wu, J.; Contreras, A.E.; Li, Q. Control of nanofiltration membrane biofouling by Pseudomonas aeruginosa using d-tyrosine. J. Membr. Sci. 2012, 423, 487-494. [CrossRef]

168. Lord, D.M.; Baran, A.U.; Wood, T.K.; Peti, W.; Page, R. BdcA, a Protein Important for Escherichia coli Biofilm Dispersal, Is a Short-Chain Dehydrogenase/Reductase that Binds Specifically to NADPH. PLoS ONE 2014, 9, e105751. [CrossRef] [PubMed]

169. Ma, Q.; Yang, Z.; Pu, M.; Peti, W.; Wood, T.K. Engineering a novel c-di-GMP-binding protein for biofilm dispersal. Environ. Microbiol. 2010, 13, 631-642. [CrossRef]

170. Ma, Q.; Zhang, G.; Wood, T.K. Escherichia coli BdcA controls biofilm dispersal in Pseudomonas aeruginosa and Rhizobium meliloti. BMC Res. Notes 2011, 4, 447. [CrossRef]

171. Singh, P.K.; Parsek, M.R.; Greenberg, E.P.; Welsh, M.J. A component of innate immunity prevents bacterial biofilm development. Nature 2002, 417, 552-555. [CrossRef]

172. Banin, E.; Vasil, M.L.; Greenberg, E.P. From The Cover: Iron and Pseudomonas aeruginosa biofilm formation. Proc. Natl. Acad. Sci. USA 2005, 102, 11076-11081. [CrossRef] [PubMed]

173. Kolodkin-Gal, I.; Elsholz, A.K.; Muth, C.; Girguis, P.; Kolter, R.; Losick, R. Respiration control of multicellularity in Bacillus subtilis by a complex of the cytochrome chain with a membrane-embedded histidine kinase. Genes Dev. 2013, 27, 887-899. [CrossRef] [PubMed] 
174. Ramos, I.; Dietrich, L.E.; Price-Whelan, A.; Newman, D.K. Phenazines affect biofilm formation by Pseudomonas aeruginosa in similar ways at various scales. Res. Microbiol. 2010, 161, 187-191. [CrossRef] [PubMed]

175. Moreau-Marquis, S.; O'Toole, G.A.; Stanton, B.A. Tobramycin and FDA-Approved Iron Chelators Eliminate Pseudomonas aeruginosa Biofilms on Cystic Fibrosis Cells. Am. J. Respir. Cell Mol. Biol. 2009, 41, 305-313. [CrossRef]

176. Nascimento, M.M.; Browngardt, C.; Xiaohui, X.; Klepac-Ceraj, V.; Paster, B.; Burne, R.A. The effect of arginine on oral biofilm communities. Mol. Oral Microbiol. 2013, 29, 45-54. [CrossRef]

177. Jakubovics, N.; Robinson, J.C.; Samarian, D.S.; Kolderman, E.; Yassin, S.A.; Bettampadi, D.; Bashton, M.; Rickard, A.H. Critical roles of arginine in growth and biofilm development by Streptococcus gordonii. Mol. Microbiol. 2015, 97, 281-300. [CrossRef]

178. He, J.; Hwang, G.; Liu, Y.; Gao, L.; Kilpatrick-Liverman, L.; Santarpia, P.; Zhou, X.; Koo, H. 1-Arginine Modifies the Exopolysaccharide Matrix and Thwarts Streptococcus mutans Outgrowth within Mixed-Species Oral Biofilms. J. Bacteriol. 2016, 198, 2651-2661. [CrossRef]

179. Kolderman, E.; Bettampadi, D.; Samarian, D.; Dowd, S.E.; Foxman, B.; Jakubovics, N.; Rickard, A.H. L-Arginine Destabilizes Oral Multi-Species Biofilm Communities Developed in Human Saliva. PLoS ONE 2015, 10, e0121835. [CrossRef]

180. Zara, G.; Zeidan, M.B.; Fancello, F.; Sanna, M.L.; Mannazzu, I.; Budroni, M.; Zara, S. The administration of L-cysteine and L-arginine inhibits biofilm formation in wild-type biofilm-forming yeast by modulating FLO11 gene expression. Appl. Microbiol. Biotechnol. 2019, 103, 7675-7685. [CrossRef]

181. Li, Y.-Y.; Li, B.-S.; Liu, W.-W.; Cai, Q.; Wang, H.-Y.; Liu, Y.-Q.; Liu, Y.-J.; Meng, W.-Y. Effects of D-arginine on Porphyromonas gingivalis biofilm. J. Oral Sci. 2020, 62, 57-61. [CrossRef]

182. Gnanadhas, D.P.; Elango, M.; Datey, A.; Chakravortty, D. Chronic lung infection by Pseudomonas aeruginosa biofilm is cured by L-Methionine in combination with antibiotic therapy. Sci. Rep. 2015, 5, 16043. [CrossRef] [PubMed]

183. Garcia, C.A.; Alcaraz, E.S.; Franco, M.A.; De Rossi, B.N.P. Iron is a signal for Stenotrophomonas maltophilia biofilm formation, oxidative stress response, OMPs expression, and virulence. Front. Microbiol. 2015, 6, 926. [CrossRef] [PubMed]

184. Lin, M.-H.; Shu, J.-C.; Huang, H.-Y.; Cheng, Y.-C. Involvement of Iron in Biofilm Formation by Staphylococcus aureus. PLoS ONE 2012, 7, e34388. [CrossRef] [PubMed]

185. Oglesby-Sherrouse, A.G.; Djapgne, L.; Nguyen, A.T.; Vasil, A.I.; Vasil, M.L. The complex interplay of iron, biofilm formation, and mucoidy affecting antimicrobial resistance of Pseudomonas aeruginosa. Pathog. Dis. 2014, 70, 307-320. [CrossRef]

186. Moreau-Marquis, S.; Bomberger, J.M.; Anderson, G.G.; Swiatecka-Urban, A.; Ye, S.; O'Toole, G.A.; A Stanton, B. The $\triangle$ F508-CFTR mutation results in increased biofilm formation by Pseudomonas aeruginosa by increasing iron availability. Am. J. Physiol. Cell. Mol. Physiol. 2008, 295, L25-L37. [CrossRef]

187. Kaneko, Y.; Thoendel, M.; Olakanmi, O.; Britigan, B.E.; Singh, P.K. The transition metal gallium disrupts Pseudomonas aeruginosa iron metabolism and has antimicrobial and antibiofilm activity. J. Clin. Investig. 2007, 117, 877-888. [CrossRef]

188. Schlag, S.; Nerz, C.; Birkenstock, T.A.; Altenberend, F.; Götz, F. Inhibition of Staphylococcal Biofilm Formation by Nitrite. J. Bacteriol. 2007, 189, 7911-7919. [CrossRef]

189. Van Alst, N.E.; Picardo, K.F.; Iglewski, B.H.; Haidaris, C.G. Nitrate Sensing and Metabolism Modulate Motility, Biofilm Formation, and Virulence in Pseudomonas aeruginosa. Infect. Immun. 2007, 75, 3780-3790. [CrossRef]

190. Dean, S.N.; Chung, M.-C.; Van Hoek, M.L. Burkholderia Diffusible Signal Factor Signals to Francisella novicida To Disperse Biofilm and Increase Siderophore Production. Appl. Environ. Microbiol. 2015, 81, 7057-7066. [CrossRef]

191. Dow, J.; Crossman, L.; Findlay, K.; He, Y.-Q.; Feng, J.-X.; Tang, J.-L. Biofilm dispersal in Xanthomonas campestris is controlled by cell-cell signaling and is required for full virulence to plants. Proc. Natl. Acad. Sci. USA 2003, 100, 10995-11000. [CrossRef]

192. Davies, D.G.; Marques, C.N.H. A Fatty Acid Messenger Is Responsible for Inducing Dispersion in Microbial Biofilms. J. Bacteriol. 2008, 191, 1393-1403. [CrossRef] [PubMed]

193. Rahmani-Badi, A.; Sepehr, S.; Babaie-Naiej, H. A combination of cis-2-decenoic acid and chlorhexidine removes dental plaque. Arch. Oral Biol. 2015, 60, 1655-1661. [CrossRef] [PubMed] 
194. Rahmani-Badi, A.; Sepehr, S.; Mohammadi, P.; Soudi, M.R.; Babaie-Naiej, H.; Fallahi, H. A combination of cis-2-decenoic acid and antibiotics eradicates pre-established catheter-associated biofilms. J. Med. Microbiol. 2014, 63, 1509-1516. [CrossRef] [PubMed]

195. Sepehr, S.; Rahmani-Badi, A.; Babaie-Naiej, H.; Soudi, M.R. Unsaturated Fatty Acid, cis-2-Decenoic Acid, in Combination with Disinfectants or Antibiotics Removes Pre-Established Biofilms Formed by Food-Related Bacteria. PLoS ONE 2014, 9, e101677. [CrossRef] [PubMed]

196. Brindle, E.R.; Miller, D.; Stewart, P.S. Hydrodynamic deformation and removal of Staphylococcus epidermidis biofilms treated with urea, chlorhexidine, iron chloride, or DispersinB. Biotechnol. Bioeng. 2011, 108, 2968-2977. [CrossRef] [PubMed]

197. Chen, X.; Stewart, P.S. Biofilm removal caused by chemical treatments. Water Res. 2000, 34, 4229-4233. [CrossRef]

198. Martinez, L.R.; Mihu, M.R.; Han, G.; Frases, S.; Cordero, R.J.; Casadevall, A.; Friedman, A.J.; Friedman, J.M.; Nosanchuk, J.D. The use of chitosan to damage Cryptococcus neoformans biofilms. Biomaterials 2010, 31, 669-679. [CrossRef]

199. Martinez, L.R.; Mihu, M.R.; Tar, M.; Cordero, R.J.B.; Han, G.; Friedman, A.J.; Friedman, J.M.; Nosanchuk, J.D. Demonstration of Antibiofilm and Antifungal Efficacy of Chitosan against Candidal Biofilms, Using an In Vivo Central Venous Catheter Model. J. Infect. Dis. 2010, 201, 1436-1440. [CrossRef]

200. Mu, H.; Guo, F.; Niu, H.; Liu, Q.; Wang, S.; Duan, J. Chitosan Improves Anti-Biofilm Efficacy of Gentamicin through Facilitating Antibiotic Penetration. Int. J. Mol. Sci. 2014, 15, 22296-22308. [CrossRef]

201. Orgaz, B.; Lobete, M.M.; Puga, C.H.; Jose, C.S. Effectiveness of Chitosan against Mature Biofilms Formed by Food Related Bacteria. Int. J. Mol. Sci. 2011, 12, 817-828. [CrossRef]

202. Zhang, A.; Mu, H.; Zhang, W.; Cui, G.; Zhu, J.; Duan, J. Chitosan Coupling Makes Microbial Biofilms Susceptible to Antibiotics. Sci. Rep. 2013, 3, 3364. [CrossRef] [PubMed]

203. Banin, E.; Brady, K.M.; Greenberg, E.P. Chelator-Induced Dispersal and Killing of Pseudomonas aeruginosa Cells in a Biofilm. Appl. Environ. Microbiol. 2006, 72, 2064-2069. [CrossRef] [PubMed]

204. De Almeida, J.; Hoogenkamp, M.; Felippe, W.T.; Crielaard, W.; Van Der Waal, S.V. Effectiveness of EDTA and Modified Salt Solution to Detach and Kill Cells from Enterococcus faecalis Biofilm. J. Endod. 2016, 42, 320-323. [CrossRef] [PubMed]

205. Jothiprakasam, V.; Sambantham, M.; Chinnathambi, S.; Vijayaboopathi, S. Candida tropicalis biofilm inhibition by ZnO nanoparticles and EDTA. Arch. Oral Biol. 2017, 73, 21-24. [CrossRef] [PubMed]

206. Lefebvre, E.; Vighetto, C.; Di Martino, P.; Véronique, L.G.; Seyer, D. Synergistic antibiofilm efficacy of various commercial antiseptics, enzymes and EDTA: A study of Pseudomonas aeruginosa and Staphylococcus aureus biofilms. Int. J. Antimicrob. Agents 2016, 48, 181-188. [CrossRef] [PubMed]

207. Liu, Z.; Lin, Y.; Lu, Q.; Li, F.; Yu, J.-L.; Wang, Z.; He, Y.; Song, C. in vitro and in vivo activity of EDTA and antibacterial agents against the biofilm of mucoid Pseudomonas aeruginosa. Infection. 2016, 45, $23-31$. [CrossRef]

208. Maisetta, G.; Grassi, L.; Di Luca, M.; Bombardelli, S.; Medici, C.; Brancatisano, F.L.; Esin, S.; Batoni, G. Anti-biofilm properties of the antimicrobial peptide temporin $1 \mathrm{~Tb}$ and its ability, in combination with EDTA, to eradicate Staphylococcus epidermidis biofilms on silicone catheters. Biofouling 2016, 32, 787-800. [CrossRef]

209. Alves, F.R.F.; Silva, M.G.; Rôças, I.N.; Siqueira, J.F., Jr. Biofilm biomass disruption by natural substances with potential for endodontic use. Braz. Oral Res. 2013, 27, 20-25. [CrossRef]

210. Ammons, M.C.B.; Copie, V. Mini-review: Lactoferrin: A bioinspired, anti-biofilm therapeutic. Biofouling 2013, 29, 443-455. [CrossRef]

211. Srivastava, D.; Waters, C.M. A Tangled Web: Regulatory Connections between Quorum Sensing and Cyclic Di-GMP. J. Bacteriol. 2012, 194, 4485-4493. [CrossRef]

212. Sauer, K.; Camper, A.K.; Ehrlich, G.D.; Costerton, J.W.; Davies, D.G. Pseudomonas aeruginosa Displays Multiple Phenotypes during Development as a Biofilm. J. Bacteriol. 2002, 184, 1140-1154. [CrossRef] [PubMed]

213. Kalia, V.C. Quorum sensing inhibitors: An overview. Biotechnol. Adv. 2013, 31, 224-245. [CrossRef] [PubMed]

214. Anderson, J.K.; Huang, J.Y.; Wreden, C.; Sweeney, E.G.; Goers, J.; Remington, S.J.; Guillemin, K. Chemorepulsion from the Quorum Signal Autoinducer-2 Promotes Helicobacter pylori Biofilm Dispersal. mBio 2015, 6, e00379-15. [CrossRef] [PubMed]

215. Mukherji, R.; Prabhune, A.A. Novel Glycolipids Synthesized Using Plant Essential Oils and Their Application in Quorum Sensing Inhibition and as Antibiofilm Agents. Sci. World J. 2014, 2014. [CrossRef] [PubMed] 
216. Dong, Y.-H.; Xu, J.-L.; Li, X.-Z.; Zhang, L.-H. AiiA, an enzyme that inactivates the acylhomoserine lactone quorum-sensing signal and attenuates the virulence of Erwinia carotovora. Proc. Natl. Acad. Sci. USA 2000, 97, 3526-3531. [CrossRef] [PubMed]

217. Rajesh, P.; Rai, V.R. Inhibition of QS-regulated virulence factors in Pseudomonas aeruginosa PAO1 and Pectobacterium carotovorum by AHL-lactonase of endophytic bacterium Bacillus cereus VT96. Biocatal. Agric. Biotechnol. 2016, 7, 154-163. [CrossRef]

218. Saipriya, K.; Swathi, C.; Ratnakar, K.; Sritharan, V.; Kamaraju, S.; Ch, S. Quorum-sensing system in Acinetobacter baumannii: A potential target for new drug development. J. Appl. Microbiol. 2019, 128, 15-27. [CrossRef]

219. Brackman, G.; Cos, P.; Maes, L.; Nelis, H.J.; Coenye, T. Quorum Sensing Inhibitors Increase the Susceptibility of Bacterial Biofilms to Antibiotics In Vitro and In Vivo. Antimicrob. Agents Chemother. 2011, 55, 2655-2661. [CrossRef]

220. Lauderdale, K.J.; Malone, C.L.; Boles, B.R.; Morcuende, J.; Horswill, A.R. Biofilm dispersal of community-associated methicillin-resistant Staphylococcus aureus on orthopedic implant material. J. Orthop. Res. 2009, 28, 55-61. [CrossRef]

221. Anguita-Alonso, P.; Giacometti, A.; Cirioni, O.; Ghiselli, R.; Orlando, F.; Saba, V.; Scalise, G.; Sevo, M.; Tuzova, M.; Patel, R.; et al. RNAIII-Inhibiting-Peptide-Loaded Polymethylmethacrylate Prevents In Vivo Staphylococcus aureus Biofilm Formation. Antimicrob. Agents Chemother. 2006, 51, 2594-2596. [CrossRef]

222. Balaban, N.; Cirioni, O.; Gov, Y.; Ghiselli, R.; Saba, V.; Scalise, G.; Dell'Acqua, G.; Giacometti, A.; Mocchegiani, F.; Viticchi, C.; et al. Use of the quorum-sensing inhibitor RNAIII-inhibiting peptide to prevent biofilm formation in vivo by drug-resistant Staphylococcus epidermidis. J. Infect. Dis. 2003, 187, 625-630. [CrossRef] [PubMed]

223. Balaban, N.; Goldkorn, T.; Nhan, R.T.; Dang, L.B.; Scott, S.; Ridgley, R.M.; Rasooly, A.; Wright, S.C.; Larrick, J.W.; Rasooly, R.; et al. Autoinducer of Virulence As a Target for Vaccine and Therapy Against Staphylococcus aureus. Science 1998, 280, 438-440. [CrossRef] [PubMed]

224. Cirioni, O.; Giacometti, A.; Ghiselli, R.; Dell'Acqua, G.; Gov, Y.; Kamysz, W.; Lukasiak, J.; Mocchegiani, F.; Orlando, F.; D’Amato, G.; et al. Prophylactic Efficacy of Topical Temporin A and RNAIII-Inhibiting Peptide in a Subcutaneous Rat Pouch Model of Graft Infection Attributable to Staphylococci With Intermediate Resistance to Glycopeptides. Circulation 2003, 108, 767-771. [CrossRef] [PubMed]

225. Cirioni, O.; Giacometti, A.; Ghiselli, R.; Acqua, G.D.; Orlando, F.; Mocchegiani, F.; Silvestri, C.; Licci, A.; Saba, V.; Scalise, G.; et al. RNAIII-Inhibiting Peptide Significantly Reduces Bacterial Load and Enhances the Effect of Antibiotics in the Treatment of Central Venous Catheter-Associated Staphylococcus aureus Infections. J. Infect. Dis. 2006, 193, 180-186. [CrossRef]

226. Simonetti, O.; Cirioni, O.; Ghiselli, R.; Goteri, G.; Scalise, A.; Orlando, F.; Silvestri, C.; Riva, A.; Saba, V.; Madanahally, K.D.; et al. RNAIII-Inhibiting Peptide Enhances Healing of Wounds Infected with Methicillin-Resistant Staphylococcus aureus. Antimicrob. Agents Chemother. 2008, 52, 2205-2211. [CrossRef]

227. Starkey, M.; Lépine, F.; Maura, D.; Bandyopadhaya, A.; Lesic, B.; He, J.; Kitao, T.; Righi, V.; Milot, S.; Tzika, A.; et al. Identification of Anti-virulence Compounds That Disrupt Quorum-Sensing Regulated Acute and Persistent Pathogenicity. PLoS Pathog. 2014, 10, e1004321. [CrossRef]

228. Rajkumari, J.; Borkotoky, S.; Murali, A.; Suchiang, K.; Mohanty, S.K.; Busi, S. Cinnamic acid attenuates quorum sensing associated virulence factors and biofilm formation in Pseudomonas aeruginosa PAO1. Biotechnol. Lett. 2018, 40, 1087-1100. [CrossRef]

229. Başaran, T.I.; Berber, D.; Gökalsın, B.; Tramice, A.; Tommonaro, G.; Abbamondi, G.R.; Hasköylü, M.E.; Öner, E.T.; Iodice, C.; Sesal, C. Extremophilic Natrinema versiforme Against Pseudomonas aeruginosa Quorum Sensing and Biofilm. Front. Microbiol. 2020, 11, 79. [CrossRef]

230. Peppoloni, S.; Pericolini, E.; Colombari, B.; Pinetti, D.; Cermelli, C.; Fini, F.; Prati, F.; Caselli, E.; Blasi, E. The $\beta$-Lactamase Inhibitor Boronic Acid Derivative SM23 as a New Anti-Pseudomonas aeruginosa Biofilm. Front. Microbiol. 2020, 11, 35. [CrossRef] [PubMed]

231. Overhage, J.; Campisano, A.; Bains, M.; Torfs, E.C.; Rehm, B.H.; Hancock, R.E. Human host defense peptide LL-37 prevents bacterial biofilm formation. Infect. Immun. 2008, 76, 4176-4182. [CrossRef] [PubMed]

232. Batoni, G.; Maisetta, G.; Esin, S. Antimicrobial peptides and their interaction with biofilms of medically relevant bacteria. Biochim. Biophys. Acta (BBA) Biomembr. 2016, 1858, 1044-1060. [CrossRef] [PubMed] 
233. Pletzer, D.; Coleman, S.R.; Hancock, R.E.W. Anti-biofilm peptides as a new weapon in antimicrobial warfare. Curr. Opin. Microbiol. 2016, 33, 35-40. [CrossRef]

234. De La Fuente-Núñez, C.; Reffuveille, F.; Mansour, S.C.; Reckseidler-Zenteno, S.L.; Hernández, D.; Brackman, G.; Coenye, T.; Hancock, R.E.W. D-enantiomeric peptides that eradicate wild-type and multidrug-resistant biofilms and protect against lethal Pseudomonas aeruginosa infections. Chem. Biol. 2015, 22, 196-205. [CrossRef]

235. Jones, E.A.; McGillivary, G.; Bakaletz, L.O. Extracellular DNA within a nontypeable Haemophilus influenzae induced biofilm binds human beta defensin-3 and reduces its antimicrobial activity. J. Innate Immun. 2012, 5, 24-38. [CrossRef] [PubMed]

236. Liu, Y.; Kamesh, A.C.; Xiao, Y.; Sun, V.; Hayes, M.; Daniell, H.; Koo, H. Topical delivery of low-cost protein drug candidates made in chloroplasts for biofilm disruption and uptake by oral epithelial cells. Biomaterials 2016, 105, 156-166. [CrossRef] [PubMed]

237. Mihailescu, R.; Tafin, U.F.; Corvec, S.; Oliva, A.; Betrisey, B.; Borens, O.; Trampuz, A. High Activity of Fosfomycin and Rifampin against Methicillin-Resistant Staphylococcus aureus Biofilm In Vitro and in an Experimental Foreign-Body Infection Model. Antimicrob. Agents Chemother. 2014, 58, 2547-2553. [CrossRef]

238. Chowdhury, N.; Wood, T.L.; Martínez-Vázquez, M.; García-Contreras, R.; Wood, T.K. DNA-crosslinker cisplatin eradicates bacterial persister cells. Biotechnol. Bioeng. 2016, 113, 1984-1992. [CrossRef]

239. Kwan, B.W.; Chowdhury, N.; Wood, T.K. Combatting bacterial infections by killing persister cells with mitomycin C. Environ. Microbiol. 2015, 17, 4406-4414. [CrossRef]

240. De La Fuente-Núñez, C.; Reffuveille, F.; Haney, E.F.; Straus, S.; Hancock, R.E.W. Broad-Spectrum Anti-biofilm Peptide That Targets a Cellular Stress Response. PLoS Pathog. 2014, 10, e1004152. [CrossRef]

241. Wang, Z.; De La Fuente-Núñez, C.; Shen, Y.; Haapasalo, M.; Hancock, R.E.W. Treatment of Oral Multispecies Biofilms by an Anti-Biofilm Peptide. PLoS ONE 2015, 10, e0132512. [CrossRef] [PubMed]

242. Mishra, B.; Golla, R.M.; Lau, K.; Lushnikova, T.; Wang, G. Anti-Staphylococcal Biofilm Effects of Human Cathelicidin Peptides. ACS Med. Chem. Lett. 2015, 7, 117-121. [CrossRef]

243. Haisma, E.M.; De Breij, A.; Chan, H.; Van Dissel, J.T.; Drijfhout, J.W.; Hiemstra, P.S.; El Ghalbzouri, A.; Nibbering, P.H. LL-37-Derived Peptides Eradicate Multidrug-Resistant Staphylococcus aureus from Thermally Wounded Human Skin Equivalents. Antimicrob. Agents Chemother. 2014, 58, 4411-4419. [CrossRef] [PubMed]

244. Haisma, E.M.; Göblyös, A.; Ravensbergen, B.; Adriaans, A.E.; Cordfunke, R.A.; Schrumpf, J.; Limpens, R.W.A.L.; Schimmel, K.J.M.; Hartigh, J.D.; Hiemstra, P.S.; et al. Antimicrobial Peptide P60.4Ac-Containing Creams and Gel for Eradication of Methicillin-Resistant Staphylococcus aureus from Cultured Skin and Airway Epithelial Surfaces. Antimicrob. Agents Chemother. 2016, 60, 4063-4072. [CrossRef] [PubMed]

245. Pompilio, A.; Scocchi, M.; Pomponio, S.; Guida, F.; Di Primio, A.; Fiscarelli, E.V.; Gennaro, R.; Di Bonaventura, G. Antibacterial and anti-biofilm effects of cathelicidin peptides against pathogens isolated from cystic fibrosis patients. Peptides 2011, 32, 1807-1814. [CrossRef] [PubMed]

246. Scarsini, M.; Tomasinsig, L.; Arzese, A.; D’Este, F.; Oro, D.; Skerlavaj, B. Antifungal activity of cathelicidin peptides against planktonic and biofilm cultures of Candida species isolated from vaginal infections. Peptides 2015, 71, 211-221. [CrossRef] [PubMed]

247. Ribeiro, S.L.S.; De La Fuente-Núñez, C.; Baquir, B.; Faria-Junior, C.; Franco, O.L.; Hancock, R.E.W. Antibiofilm Peptides Increase the Susceptibility of Carbapenemase-Producing Klebsiella pneumoniae Clinical Isolates to $\beta$-Lactam Antibiotics. Antimicrob. Agents Chemother. 2015, 59, 3906-3912. [CrossRef] [PubMed]

248. Ahire, J.J.; Kashikar, M.S.; Lakshmi, S.G.; Madempudi, R. Identification and characterization of antimicrobial peptide produced by indigenously isolated Bacillus paralicheniformis UBBLi30 strain. 3 Biotech 2020, 10, 112-113. [CrossRef]

249. Kokilakanit, P.; Koontongkaew, S.; Roytrakul, S.; Utispan, K. A novel non-cytotoxic synthetic peptide, Pug-1, exhibited an antibiofilm effect on Streptococcus mutans adhesion. Lett. Appl. Microbiol. 2020, 70, 151-158. [CrossRef]

250. Von Borowski, R.G.; Barros, M.P.; Da Silva, D.B.; Lopes, N.P.; Zimmer, K.R.; Staats, C.C.; De Oliveira, C.B.; Giudice, E.; Gillet, R.; Macedo, A.J.; et al. Red pepper peptide coatings control Staphylococcus epidermidis adhesion and biofilm formation. Int. J. Pharm. 2020, 574, 118872. [CrossRef] 
251. Xie, Z.; Wei, H.; Meng, J.; Cheng, T.; Song, Y.; Wang, M.; Zhang, Y. The Analogs of Temporin-GHa Exhibit a Broader Spectrum of Antimicrobial Activity and a Stronger Antibiofilm Potential against Staphylococcus aureus. Molecules 2019, 24, 4173. [CrossRef]

252. Martínez, M.; Polizzotto, A.; Flores, N.; Semorile, L.; Maffia, P. Antibacterial, anti-biofilm and in vivo activities of the antimicrobial peptides P5 and P6.2. Microb. Pathog. 2020, 139, 103886. [CrossRef] [PubMed]

253. Zhong, H.; Xie, Z.; Zhang, S.; Wei, H.; Song, Y.; Zhang, Y.; Wang, M. Brevinin-GR23 from frog Hylarana guentheri with antimicrobial and antibiofilm activities against Staphylococcus aureus. Biosci. Biotechnol. Biochem. 2019, 84, 143-153. [CrossRef] [PubMed]

254. Chua, S.L.; Liu, Y.; Yam, J.K.H.; Chen, Y.; Vejborg, R.M.; Tan, B.G.C.; Kjelleberg, S.; Tolker-Nielsen, T.; Givskov, M.; Yang, L. Dispersed cells represent a distinct stage in the transition from bacterial biofilm to planktonic lifestyles. Nat. Commun. 2014, 5, 4462. [CrossRef] [PubMed]

255. Ding, Q.; Tan, K.S. The Danger Signal Extracellular ATP Is an Inducer of Fusobacterium nucleatum Biofilm Dispersal. Front. Microbiol. 2016, 6, 155. [CrossRef]

(C) 2020 by the authors. Licensee MDPI, Basel, Switzerland. This article is an open access article distributed under the terms and conditions of the Creative Commons Attribution (CC BY) license (http://creativecommons.org/licenses/by/4.0/). 